\title{
Tholeiitic- and boninite-series metabasites of the Nové Město Unit and northern part of the Zábřeh Unit (Orlica-Śnieżnik Dome, Bohemian Massif): petrogenesis and tectonic significance
}

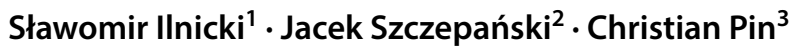 \\ Received: 29 May 2019 / Accepted: 3 March 2020 / Published online: 3 April 2020 \\ (c) The Author(s) 2020
}

\begin{abstract}
The Nové Město Unit and the northern part of the Zábřeh Unit comprise back-arc basin mafic rocks metamorphosed during Variscan times. In both units, nearly identical metabasites comprise variously enriched tholeiites (from N-MORB to transitional E-MORB-OIB), high-Ca, low-silica boninites and low-Ti tholeiites. The tholeiites (Ti/V: $22-58, \varepsilon^{2} \mathrm{Nd}_{540}:+7.6$ to -4.7 ) represent $10-15 \%$ melting at ca. $30-60 \mathrm{~km}$ and temperatures of $1380-1230{ }^{\circ} \mathrm{C}$ of a depleted MORB mantle-type (DMM) wedge heterogeneously modified shortly before fusion by OIB-like melts (enriched mantle possibly of EM1-EM2 type) presumably derived from decompression melting of upwelling asthenosphere. Much less common meta-boninites (Ti/V: 6-23, $\varepsilon \mathrm{Nd}_{540}:+6.7$ to -2.9 ) formed by $15-25 \%$ re-melting of residual mantle (DMM after $~ 15 \%$ melt extraction) at depths of $40-65 \mathrm{~km}$ and temperatures of $\sim 1420-1300{ }^{\circ} \mathrm{C}$. Scarce low-Ti meta-tholeiites (Ti/V: $\left.18-19, \varepsilon \mathrm{Nd}_{540}:+7.1\right)$ resulted from $<10 \%$ melting of an unenriched DMM-type source or re-melting of residual mantle (after $<15 \%$ of former melting). Trace elements and $\mathrm{Nd}$ isotope compositions imply random fluxing of tholeiitic- and boninitic magma sources by components released from a subducted slab. The metasomatic enrichment (Th, LREE-MREE) was induced not only by sediment-derived melts but also by fluids supplied by subducted sediments or juvenile crust. The Nové Město-Zábřeh association of metabasites points to an easterly prolongation (in present-day coordinates) of the Cadomian subduction system of the Teplá-Barrandian. Boninite-type magmatism and OIB-like input into mantle beneath an extensional back-arc basin suggest an upflow of hot asthenosphere through subducted ridge (slab window) followed by a cessation of subduction zone activity.
\end{abstract}

Keywords Tholeiites · Boninites · Trace elements $\cdot$ Nd isotopes $\cdot$ Back-arc basin · Orlica-Śnieżnik dome

\section{Introduction}

Electronic supplementary material The online version of this article (https://doi.org/10.1007/s00531-020-01845-5) contains supplementary material, which is available to authorized users.

Sławomir Ilnicki

slawomir.ilnicki@uw.edu.pl

1 Institute of Geochemistry, Mineralogy and Petrology, Faculty of Geology, University of Warsaw, Al. Żwirki i Wigury 93, 02-089 Warsaw, Poland

2 Institute of Geological Sciences, Faculty of Earth Science and Environmental Management, University of Wroclaw, Pl. Maksa Borna 9, 50-205 Wrocław, Poland

3 Département de Géologie, C.N.R.S. Campus des Cézeaux, 6 Avenue Blaise Pascal, TSA 60026-CS 60026, 63178 Aubière Cedex, France
The association of tholeiites and boninites commonly occurs in many subduction-related ophiolites, in orogenic sutures delineating ancient subduction-accretion belts at active continental margins, and in fore-arc domains, e.g., the Izu-Bonin-Mariana system (e.g., Bédard 1999; König et al. 2010; Dilek and Furnes 2014). The internal relationships and transitions between the rock types occurring in the Izu-Bonin-Mariana system (MORB-type basalts, low-Ti island arc tholeiites, boninites, calc-alkaline magmas, etc.) has resulted in chemostratigraphic models which emphasize boninitic melt generation concurrent with subduction initiation (e.g., Ishizuka et al. 2006; Diley and Thy 2009; Reagan et al. 2017). However, there are also reports of boninite-tholeiite suites formed at later periods of suprasubduction zone activity (Woelkl et al. 2018) and in back-arc domains (Xia et al. 2012; Hajná et al. 2013). Specifically, it 


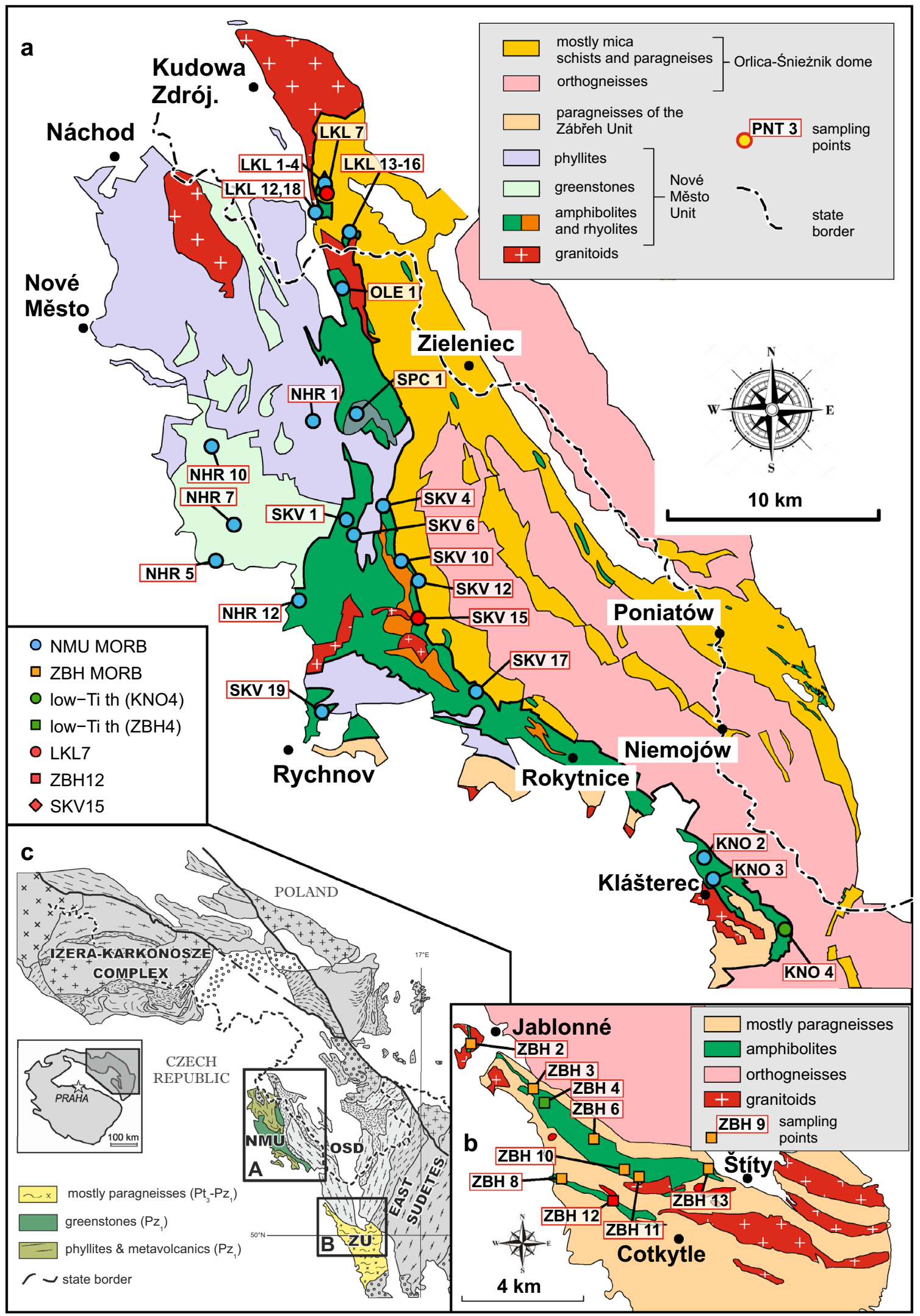


४Fig. 1 Geological sketch map of a the Nové Město Unit (NMU; after Mazur et al. 2005) and b the Zábřeh Unit (ZU; after Buriánek et al. 2003). The inset shows the location of the units within the Sudetes and the Bohemian Massif (after Mazur et al. 2005)

has been proposed that the appearance of a variegated rock assemblage including boninites, MORB-type and arc tholeiites and alkaline OIB-type basalts is linked to cessation of subduction zone activity due to collision of an active divergent ridge with the trench followed by the opening of a slab window. (e.g., Thorkelson 1996; König et al. 2010; Hajná et al. 2018; Windley and Xiao 2018). Furthermore, the rare boninites are particularly interesting as they are believed to originate from the extremely depleted, refractory portion of the mantle wedge fluxed by copious melts and fluids released from the subducted slab (e.g., Hickey and Frey 1982). Consequently, they primarily reflect the nature of the slab components, their elemental abundances and migration through the mantle wedge (e.g., Crawford et al. 1989; Plank 2005; König et al. 2010). The accompanying tholeiitic magmas are frequently derived from fertile sources and their geochemical features are to great extent controlled by contributions from the mantle wedge. Thus, boninites and associated rocks offer valuable insights into the supra-subduction zone environment; they are highly effective markers of the magmatic- and tectonic processes taking place in arc systems at convergent margins.

Our current study focuses on the Nové Město and Zábřeh Units forming the metavolcano-sedimentary envelope around the core of the Orlica-Śnieżnik Dome (Fig. 1c) where ca. $500 \mathrm{Ma}$ orthogneisses are intercalated with the 530-560 Ma volcano-sedimentary succession (Chopin et al. 2012). Recent geochemical studies have shown that the core has Saxothuringian affinities (Mazur et al. 2012, 2015; Szczepański and Ilnicki 2014) and comprises metabasites that formed during the transition from the Cadomian back-arc basin environment to incipient Early Palaeozoic rifting (Ilnicki et al. 2013). They argued that these magmatic episodes were linked to the cessation of supra-subduction zone activity triggered by ridge-trench collision, opening of a slab window and upwelling of sub-slab asthenosphere. In contrast, much less is known about the envelope. Though rifting- or back-arc basin settings for the metabasic rocks of the Nové Město have been proposed (Opletal et al. 1990; Floyd et al. 1996; Ilnicki 2013), the Zábřeh Unit metabasites lack any comprehensive investigation. Thus, new bulk-rock geochemical- and $\mathrm{Nd}$ isotopic data for metabasites in the northern part of the Zábřeh Unit that augment the extended dataset of Ilnicki (2013) are presented here. The geochemical features of these rocks show them to be tholeiites, lowTi tholeiites and boninites. The latter are reported for the first time from the envelope of the Orlica-Śnieżnik Dome. The results are discussed below in terms of subduction zone input and mantle source characteristics. Based on geochemical modeling, a petrogenetic model is proposed which involves a two-stage development of the back-arc domain terminated by the ridge subduction, and a slab window opening and generation of boninitic magma at the end of the subduction zone activity. We also argue that regional correlations unequivocally recognize the Nové Město and Zábřeh Units to be an easterly extension of the Teplá-Barrandian Unit and part of the Cadomian active margin located between the Davle arc complex and the Gondwana mainland (see Hajná et al. 2018).

\section{Geologic setting}

The Sudetes expose a Neoproterozoic volcano-sedimentary succession and metamorphosed Cambro-Ordovician granites that are interpreted to represent various crustal domains. From NW to SE, these rocks belong to the Saxothuringian Domain, including low- to medium-grade complexes of the Izera-Karkonosze Complex and the Orlica-Śnieżnik Dome and the Brunovistulian domain embodying the East Sudetes (Fig. 1; e.g., Mazur et al. 2010, 2012, 2015; Szczepański and Ilnicki 2014). However, rock successions that mantle the Orlica-Śnieżnik Dome on the west and south have been considered to represent fragments of the Teplá-Barrandian Domain (Cháb et al. 1995; Mazur et al. 2005). These comprise low- to medium-grade volcano-sedimentary successions in the Nové Město Unit in the west and the Zábřeh Unit in the south (Fig. 1). To the west, the Orlica-Śnieżnik Dome is rimmed by a low-grade NE-SW to NNW-SSE trending belt comprising metapelites and basic- and acid metavolcanics of the Nové Město Unit of inferred Neoproterozoic age (e.g., Buriánek et al. 2003). This succession is intruded by Carboniferous granodiorites and tonalites (Bachliński and Hałas 2002). The southern part of the Orlica-Śnieżnik Dome is bordered by the Zábřeh Unit including WNW-ESE belts of a metamorphosed, low- to medium-grade volcanosedimentary succession (Verner et al. 2009). The whole succession in the Zábřeh Unit comprises, in the north, amphibolites, paragneisses and calc-silicate schists intruded by granitoid sheets which, in the south, pass into metapelites, phyllites and acid metavolcanic rocks (Buriánek et al. 2003; Verner et al. 2009).

The metabasalts in the Nové Město Unit have been described as varying from WPB- to MORB-like tholeiites showing various degrees of crustal contamination (Floyd et al. 1996). The latter feature enabled the conclusion that the metabasalts are representative of an early phase of the early Palaeozoic fragmentation of Gondwana when oceanic crust had not fully developed (Floyd et al. 1996). However, recently published data have shown that metabasalts of the Nové Město Unit grade from E-MORB and N-MORB to 
OIB types that originated in a back-arc basin (Ilnicki 2013). This accords with a recent interpretation of the metabasalts in the western part of the Orlica-Śnieżnik Dome (Ilnicki et al. 2013). Limited geochemical data for amphibolites in the Zábřeh Unit point to MORB-type metabasalts in the northern part of the unit grading to WP-type metabasalts in the southern part (Melichar and Hanžl 1997).

Protolith ages for the rocks in both the Nové Městoand the Zábřeh Units are unknown. However, their lithological compositions are believed to correspond to those of the Teplá-Barrandian Domain (e.g., Mísař and Dudek 1993; Buriánek et al. 2003). This domain is a crustal segment located between the Saxothuringian to the NE and the Moldanubian domains to the SW. Its Neoproterozoic basement is commonly interpreted to be a fragment of the Avalonian-Cadomian belt developed along the northern active margin of Gondwana during the late Neoproterozoic to earliest Cambrian (e.g., Nance et al. 2010). In general, the Neoproterozoic volcano-sedimentary succession in the Teplá-Barrandian Domain is believed to represent, from NW to SE, remnants of a metaophiolitic complex (Mariánské Lázně Complex), an accretionary wedge (Blovice Formation), a volcanic arc (Davle Formation) and intra-arc and back-arc basins (Štěchovice Group and Svrchnice Formation; e.g., Sláma et al. 2008; Hajná et al. 2018). Geochemically, the basaltic blocks in this melange are moderately LREE-enriched within-plate basalts and basalts generated in an intraoceanic, suprasubduction zone to back-arc basin setting (Pin and Waldhausrová 2007). The Davle Group includes low-Ti tholeiitic basalts with an island arc signature, rare boninites, calc-alkaline andesites, dacites and Na-rhyolites. The ages of the successions in this volcanic complex range from $610 \pm 17$ to $563 \pm 7 \mathrm{Ma}$ (Sláma et al. 2008; Hajná et al. 2018). The overlying Štěchovice Group comprises siliciclastics with rare rhyolitic pebbles of felsic volcanic rocks and granites. Detrital zircons in these rocks reveal maximum depositional ages of $580 \mathrm{Ma}$ (Hajná et al. 2018).

\section{Analytical methods}

The study is based on 102 samples from the Nové Město Unit and 16 samples from the northern part of the Zábřeh Unit. A set of 37 samples (29 from the Nové Město Unit and 8 from the Zábřeh Unit; Fig. 1) selected for major- and trace element analysis includes all the main lithologies in both units. These samples show minimal retrogression alteration. They were cut with a diamond saw to remove secondary veins and weathered surfaces, washed, crushed in a steel jaw-crusher and powdered in an agate ball mill. The whole-rock major- and trace element concentrations were determined at the laboratories of Acme Ltd, Vancouver,
Canada. The powdered samples were fused with lithium metaborate, digested in dilute nitric acid and analyzed on a Perkin-Elmer Elan 9000 ICP-mass spectrometer. The results are in Table $\mathrm{S} 1$.

Whole-rock Sm-Nd isotope data were measured by thermal ionization mass spectrometry (TIMS) at the CNRS Laboratories in Clermont-Ferrand and Nîmes (France). A total of 17 samples represent all types of metabasites (12 meta-tholeiites, 2 low-Ti meta-tholeiites and 3 meta-boninites). The rock powders were decomposed by fusion in an induction furnace with a lithium metaborate flux following the procedure of LeFèvre and Pin (2005). A combination of cation-exchange and extraction chromatography techniques, adapted from those detailed by Pin and Santos Zalduegui (1997), was used to separate Sm and Nd from matrix elements and from each other. Concentrations of Sm were determined by isotope dilution with a ${ }^{149} \mathrm{Sm}$-enriched tracer and an upgraded VG54E mass spectrometer (ClermontFerrand). Concentrations of $\mathrm{Nd}$, and ${ }^{143} \mathrm{Nd} /{ }^{144} \mathrm{Nd}$ ratios, were measured with a ${ }^{150} \mathrm{Nd}$-enriched tracer and a Triton TI spectrometer (GIS Laboratory, Nîmes) with normalization to ${ }^{146} \mathrm{Nd} /{ }^{144} \mathrm{Nd}=0.7219$. The JNdi-1 standard (Japanese Geological Survey) gave a value of ${ }^{143} \mathrm{Nd} /{ }^{144} \mathrm{Nd}=0.512101 \pm 4$ (2 standard error). A batch of samples was analyzed using MC-ICP-MS instead of TIMS. In brief, values of ${ }^{143} \mathrm{Nd} /{ }^{144} \mathrm{Nd}$ were measured from a purified $\mathrm{Nd}$ fraction with a Neptune Plus instrument using standard static multicollection methods with mass bias correction by normalization to ${ }^{146} \mathrm{Nd} /{ }^{144} \mathrm{Nd}=0.7219$, and are given relative to ${ }^{143} \mathrm{Nd} /{ }^{144} \mathrm{Nd}=0.512115$ for the JNdi-1 isotope reference. On an aliquot of the LREE fraction separated from major- and other trace elements using a TRU Spec extraction chromatographic column, ${ }^{147} \mathrm{Sm} /{ }^{144} \mathrm{Nd}$ values were deduced from measured ${ }^{147} \mathrm{Sm} /{ }^{146} \mathrm{Nd}$ values following a procedure adapted from Pin et al. (1995) and Sanchez et al. (2012). The results are in Table $\mathrm{S} 2$.

\section{Results}

\section{Petrographic outline}

The investigated metabasalts are mostly amphibolites and greenstones. The latter are preserved in the western part of the Nové Město Unit and indicate an increase in metamorphic grade towards the core of the Orlica-Śnieżnik Dome. In the Zábřeh Unit, all the collected metabasalts are amphibolites.

The metabasalts of the Nové Město Unit are medium- to coarse-grained and comprise mostly amphibole, plagioclase, chlorite, epidote and subordinate quartz, sphene or ilmenite, rare garnet porphyroblasts and calcite. These rocks range from undeformed and massive to strongly deformed with 
a pronounced foliation. Primary textures preserved in less deformed varieties indicate protoliths of porphyritic basalts with subordinate dolerites and gabbros.

The metabasites of the Zábřeh Unit are medium- to coarse-grained mostly finely laminated rocks. Some contain amphibole porphyroblasts. The most typical mineral assemblage comprises amphibole, plagioclase, epidote and subordinate quartz, sphene or ilmenite, and occasional calcite. Several samples contain fine-grained pyroxene blasts as laminae or thin lenses elongated parallel to the lamination. Though they may represent original magmatic grains recrystallized, the textures suggest that the pyroxene grains are metamorphic.

\section{Geochemical characteristics}

\section{Metabasites of the Nové Město Unit}

The Nové Město metabasites are characterized by a narrow range (46.2-52.9 wt\%) of $\mathrm{SiO}_{2}$ typical of basaltic compositions and by fairly variable contents of $\mathrm{TiO}_{2}(0.3-3.9 \mathrm{wt} \%)$, $\mathrm{MgO}$ (3.6-11.5 wt\%), $\mathrm{Fe}_{2} \mathrm{O}_{3}{ }^{\text {tot }}(7.2-14.9 \mathrm{wt} \%)$ and $\mathrm{P}_{2} \mathrm{O}_{5}$ (<0.5 wt \%; Table 1S). Their Mg\# (molar $100 \mathrm{MgO} /$ $(\mathrm{MgO}+\mathrm{FeO})$, assuming $\left.\mathrm{Fe}_{2} \mathrm{O}_{3} / \mathrm{FeO}=0.15\right)$ indicate significant fractionation as the values vary considerably from 75 to 37 . Consequently, on Harker diagrams, the rocks show negative correlations of $\mathrm{TiO}_{2}, \mathrm{P}_{2} \mathrm{O}_{5}$ and $\mathrm{Fe}_{2} \mathrm{O}_{3}$ with $\mathrm{Mg} \#$ and less distinct, slightly positive correlations for $\mathrm{Al}_{2} \mathrm{O}_{3}$ and $\mathrm{CaO}$ (Fig. S1). The concentrations of compatible elements (in ppm), i.e., Cr (60-630), Ni (23-162), Co (24-58) and $\mathrm{V}$ (194-479) and their variation against incompatible elements (e.g., Y, not shown) suggest fractional crystallization of mafic minerals (olivine, clinopyroxene and possibly spinel). However, the systematic increase of chondrite-normalized La/Sm vs La concentration (Fig. S2) indicates that the degree of partial melting also controlled the chemical composition of the rocks.

The metabasites are characterized by variable contents of incompatible elements (REE and HFSE) exemplified by the concentration ranges of $\Sigma$ REE (6-203 ppm) or $\mathrm{Zr}$ (12-369 ppm). The compositional diversity of the rocks is conspicuous on the $\mathrm{Zr} / \mathrm{TiO}_{2}$ vs $\mathrm{Nb} / \mathrm{Y}$ diagram of Winchester and Floyd (1977; Fig. 2a) and is further emphasized by other elemental ratios. The prevailing group of samples plots in the andesite/basalts field and shows subalkaline affinities $(\mathrm{Nb} / \mathrm{Y}=0.11-0.33)$. These rocks also have moderate $\mathrm{Ti} / \mathrm{V}$ (22-49), Zr/Nb (15-32), Zr/Y (2.71-5.68), Nb/Yb (1.11-3.21) and $\mathrm{La} / \mathrm{Nb}$ (0.94-1.38). Furthermore, their REE chondrite-normalized $(\mathrm{CN})$ profiles and primitive mantlenormalized multi-element diagrams (not shown) display, in most cases, variable yet generally mild enrichment of LREE over MREE and HREE. Distinct LREE depletion is less common $\left([\mathrm{La} / \mathrm{Sm}]_{\mathrm{CN}}=0.75-1.58 ;[\mathrm{La} / \mathrm{Yb}]_{\mathrm{CN}}=1.02-2.63\right)$. The resulting REE patterns are flat or mostly show a gentle negative slope at $\sim 20$ to $60 \times$ chondrite for LREE and $\sim 12$ to $25 \times$ chondrite for HREE (Fig. 3). The fractionation of MREE from HREE is rather weak $\left([\mathrm{Tb} / \mathrm{Yb}]_{\mathrm{CN}}=1.20-1.48\right)$ and denotes a spinel-bearing mantle source free of residual garnet during the melting event. Values of the Eu anomaly range from absent to fairly positive $\left(\mathrm{Eu} / \mathrm{Eu}^{*}=0.98-1.29\right.$, aver. $1.14 \pm 0.12$ ) and, assuming a divalent oxidation state of Eu, suggest that some samples record a significant accumulation of plagioclase in the magma chamber. On the $\mathrm{N}$-MORB-normalized diagrams, a negative $\mathrm{Nb}$ anomaly is
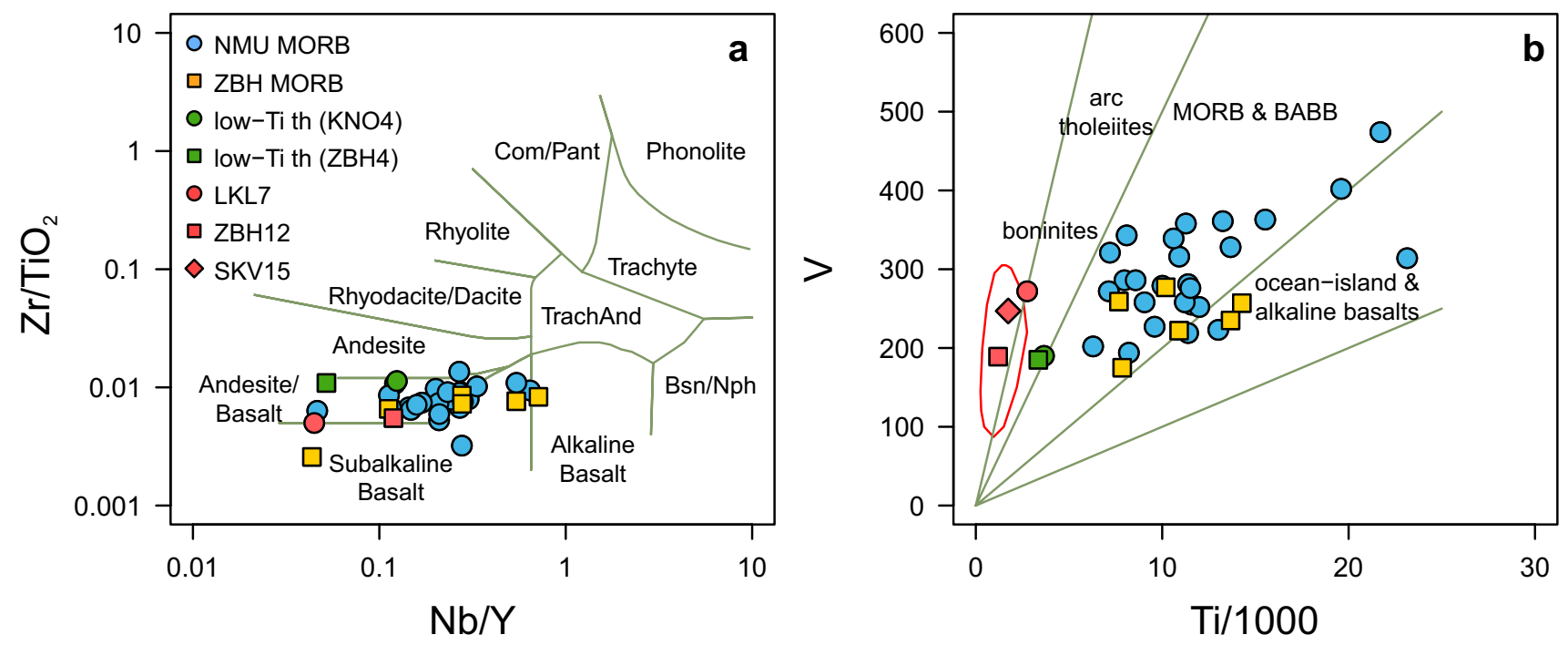

Fig. 2 a. $\mathrm{Zr} / \mathrm{TiO}_{2}$ vs $\mathrm{Nb} / \mathrm{Y}$ plot (Winchester and Floyd 1977) and b V-Ti diagram (Shervais 1982) for the metabasites analyzed. Symbols: bluethe Nové Město Unit meta-tholeiites, yellow—-the Zábřeh Unit meta-tholeiites, green—low-Ti meta-tholeiites, red-meta-boninites 

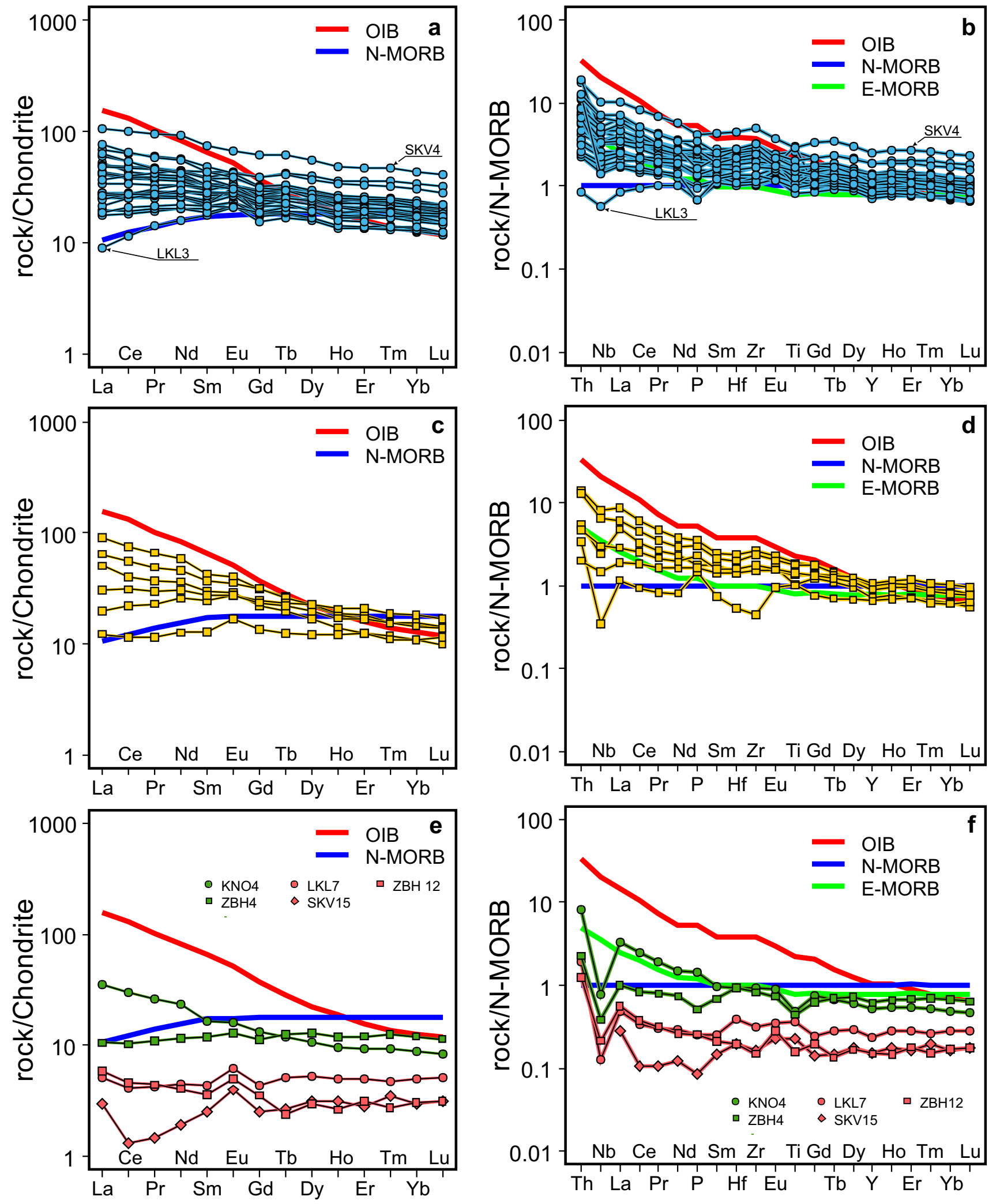

Fig. 3 Chondrite-normalized REE and N-MORB-normalized multielement patterns for meta-tholeiites from the Nové Město Unit $(\mathbf{a}, \mathbf{b})$ and the Zábřeh Unit (c, d), and for meta-boninites and low-Ti meta-

tholeiites from both units $(\mathbf{e}, \mathbf{f})$. Profiles for OIB and N-MORB are given for comparison. The normalization chondrite- and N-MORB values are from Sun and McDonough (1989) 
common and profiles show moderate enrichment at $\sim 2$ to $10 \times \mathrm{N}$-MORB for the most incompatible elements and $\sim 0.7$ to $1.2 \times \mathrm{N}-\mathrm{MORB}$ for HREE corresponding to transitional magmas of E-MORB affinity (Fig. 3). Independent of the $\mathrm{Nb}$ depletion, the dominant group of rocks has a radiogenic $\mathrm{Nd}$ isotope signature (initial $\varepsilon \mathrm{Nd}_{540}$ values from +2.6 to +5.9 ) reflecting a depleted mantle source on a time-integrated basis. For sample LKL3, an even more radiogenic isotope composition $\left(\varepsilon \mathrm{Nd}_{540}:+6.2\right)$ couples with a distinct tholeiitic affinity $(\mathrm{Nb} / \mathrm{Y}=0.05$; Fig. 2a) and a close resemblance to $\mathrm{N}-\mathrm{MORB}$ composition in terms of the incompatible-element patterns (though with negative $\mathrm{Nb}$ and $\mathrm{P}$ anomalies) and elemental ratios (Table $1 \mathrm{~S}$ and Fig. 3). Notably, sample SKV4 $\left(\varepsilon \mathrm{Nd}_{540}=+5.8\right)$ shows a remarkably high concentrations of incompatible elements (LREE $=\sim 100 \times$ chondrite, HREE $=\sim 40 \times$ chondrite), suggesting that this sample represents strongly fractionated melt $(\mathrm{Mg} \# 43$; low content of compatible elements: $\mathrm{Cr}=130 \mathrm{ppm}$ and $\mathrm{Ni}=46 \mathrm{ppm}$ ) derived from a depleted mantle source on a secular basis.

A subgroup of samples (KNO2, $\mathrm{KNO} 3)$ has geochemical features consistent with mildly alkaline-type magmas, enriched relative to E-MORB and akin to within-plate basalts (Table 1S; Figs. 2, 3 and 4). Compared to other Nové Město metabasites, they have the highest $\mathrm{Nb} / \mathrm{Y}(0.54-0.64)$, $\mathrm{Zr} / \mathrm{Y}$ (7.52-7.72), Nb/Yb (5.76-6.57; Fig. 5), much higher $\mathrm{Ti} / \mathrm{V}$ (52-58), the lowest $\mathrm{Zr} / \mathrm{Nb}$ (12-14) but similar values of $\mathrm{Th} / \mathrm{Nb}(0.09)$ and $\mathrm{La} / \mathrm{Nb}(0.97-1.08)$. Their patterns on all normalized incompatible-element diagrams are steep and negative due to pronounced fractionation of LREE over $\operatorname{HREE}\left([\mathrm{La} / \mathrm{Yb}]_{\mathrm{CN}}=4.45-4.59\right)$. Moreover, the value of $[\mathrm{Tb} /$ $\mathrm{Yb}]_{\mathrm{CN}}(1.66-1.74)$ suggests that garnet may have been a residual phase in the mantle source. The rocks also show only a slight depletion in $\mathrm{Nb}$ and a modest enrichment in $\mathrm{Zr}$ and Hf. However, the mildly radiogenic $\varepsilon \mathrm{Nd}_{540}$ value $(+2.8)$ of sample KNO3 indicates a mantle source depleted for a long time. The geochemical features of these samples suggest that their source could have experienced relatively recent enrichment by incompatible element-rich components, e.g., alkaline, low-degree partial melts.

Another subgroup (samples LKL7 and SKV15) stands in marked contrast to the rest. Their contents of $\mathrm{TiO}_{2}$ (0.29-0.46 wt\%) and of $\mathrm{MgO}(9.26-11.50 \mathrm{wt} \%$ and $\mathrm{Mg \#}$ of 71-74) are at the low- and high ends of the data spectrum, respectively (Table 1S; Fig. 4d, e and S1). Their REE and HFSE concentrations are also the lowest amongst the studied, i.e., $\Sigma$ REE (6-12 ppm), HREE (2-4 ppm), Zr (12-23 ppm), Y (4.3-6.7 ppm) and $\mathrm{Nb}(0.3 \mathrm{ppm})$ in sample LKL7 (Nb below the detection limit of $0.2 \mathrm{ppm}$ in SKV15). Accordingly, values of $\mathrm{Ti} / \mathrm{V}$ (12-23), $\mathrm{Zr} / \mathrm{Y}$ (2.79-3.43), $\mathrm{Nb} / \mathrm{Y}(0.04), \mathrm{Nb} / \mathrm{Yb}(0.35)$ and $\mathrm{La} / \mathrm{Nb}$ (4.00) are the lowest and those of $\mathrm{Zr} / \mathrm{Nb}(77)$ and $\mathrm{Th} / \mathrm{Nb}(0.77)$ the highest in the suite. Cr contents vary widely (90-1390 ppm), but those of $\mathrm{Ni}(70-113 \mathrm{ppm})$ are moderate. The REE profiles show only a slight positive slope in the MREE-HREE segment $\left([\mathrm{La} / \mathrm{Yb}]_{\mathrm{CN}}=1.00,[\mathrm{La} / \mathrm{Sm}]_{\mathrm{CN}}=1.16-1.17,[\mathrm{~Tb} /\right.$ $\left.\mathrm{Yb}]_{\mathrm{CN}}=0.95-1.00\right)$ at very low levels relative to chondrite ( $\sim 1$ to $5 \times$ chondrite; Fig. $3 \mathrm{e}$ ). The overall strong depletion in incompatible elements is prominent on N-MORB-normalized plots (at $\sim 0.11$ to $0.39 \times \mathrm{N}$-MORB; Fig. $3 f$ ) with deep negative $\mathrm{Nb}$ anomalies, positive $\mathrm{Th}$ and $\mathrm{La}$ anomalies and weak positive $\mathrm{Zr}$, Hf, Eu and Ti anomalies evident. Moderate $\left(\varepsilon \mathrm{Nd}_{540}=+2.9\right.$ for LKL7) or strongly radiogenic $\mathrm{Nd}$ isotope signatures $\left(\varepsilon \mathrm{Nd}_{540}=+6.7\right.$ for SKV15; Table $\left.2 \mathrm{~S}\right)$ imply a depleted mantle source presumably variously affected by a contrasting, non-radiogenic $\mathrm{Nd}$ isotope component with a low initial $\varepsilon \mathrm{Nd}$ and $\mathrm{Sm} / \mathrm{Nd}$, e.g., recycled crustal material ( e.g., Zindler and Hart 1986; Taylor and McLennan 1995). The low $\mathrm{TiO}_{2}$ contents, high $\mathrm{Mg} \#, \mathrm{CaO} / \mathrm{Al}_{2} \mathrm{O}_{3}$ of $0.8-1.1$, $\mathrm{Al}_{2} \mathrm{O}_{3} / \mathrm{TiO}_{2}$ of $22.4-56.4$ and strongly depleted HREE and HFSE concentrations of the subgroup point to a close resemblance to high-Ca boninitic-type basalts (Figs $\mathrm{S} 1$ and 4). These particular geochemical features are, to a degree, shared by sample KNO4 (Table 1s; Figs. 3 and 4).

\section{Metabasites of the Zábřeh Unit}

The metabasites from the northern part of the Zábřeh Unit display strong geochemical similarities to those of the Nové Město Unit. $\mathrm{SiO}_{2}$ contents (46.4-54.6 wt\%) correspond mainly to those of basalts with high $\mathrm{Al}_{2} \mathrm{O}_{3}(14.6-18.6 \mathrm{wt} \%)$ and variable $\mathrm{TiO}_{2}(0.2-2.4 \mathrm{wt} \%), \mathrm{MgO}$ (4.6-9.4 wt\%), $\mathrm{Fe}_{2} \mathrm{O}_{3}{ }^{\text {tot }}(7.2-13.3 \mathrm{wt} \%)$ and $\mathrm{P}_{2} \mathrm{O}_{5}(<0.4 \mathrm{wt} \%)$. The range of $\mathrm{Mg \#} \mathrm{(74-45)} \mathrm{and} \mathrm{the} \mathrm{trends} \mathrm{on} \mathrm{Harker} \mathrm{diagrams} \mathrm{(Fig.}$ S1) coupled with the concentrations of compatible elements (e.g., Cr 80-400 ppm and Ni 47-274 ppm) could be attributed to fractionation of predominantly olivine and clinopyroxene ( \pm spinel). However, these features might also reflect increasing degrees of partial melting as signaled by the positive trend between $[\mathrm{La} / \mathrm{Sm}]_{\mathrm{CN}}$ and $\mathrm{La}$ (Fig. S2).

Incompatible trace-element concentrations and their ratios reveal a substantial compositional diversity of the Zábřeh metabasites matching that seen in the Nové Město Unit (Table 1S; Figs. 2, 3, 4, 5 and S1-S3). Values of Nb/Y (0.04-0.71) and their position on the classification diagram (Fig. 2) denote a prevailing tholeiitic basalt affinity with a subgroup of transitional mildly alkaline rocks (samples ZBH2, ZBH6). The chondrite- (Fig. 3c) and primitive mantle-normalized (not shown) diagrams show profiles sloping from positive $\left([\mathrm{La} / \mathrm{Yb}]_{\mathrm{CN}}=4.60-6.14\right.$ and $[\mathrm{La} /$ $\mathrm{Sm}]_{\mathrm{CN}}=1.75-2.15$ for mildly alkaline rocks) to slightly negative $\left([\mathrm{La} / \mathrm{Yb}]_{\mathrm{CN}}=1.08-1.18\right.$ and $[\mathrm{La} / \mathrm{Sm}]_{\mathrm{CN}}=0.80-0.96$ for tholeiitic rocks) due to variable degrees of enrichment of LREE over MREE-HREE. A weak fractionation of MREE to HREE $\left([\mathrm{Tb} / \mathrm{Yb}]_{\mathrm{CN}}=1.16-1.66\right)$ is indicative of spinelbearing peridotite-facies mantle, i.e., a mantle source devoid of residual garnet; only a higher $[\mathrm{Tb} / \mathrm{Yb}]_{\mathrm{CN}}(1.80-1.81)$ for 


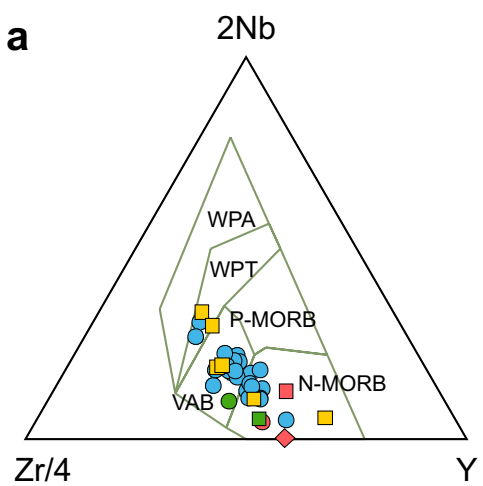

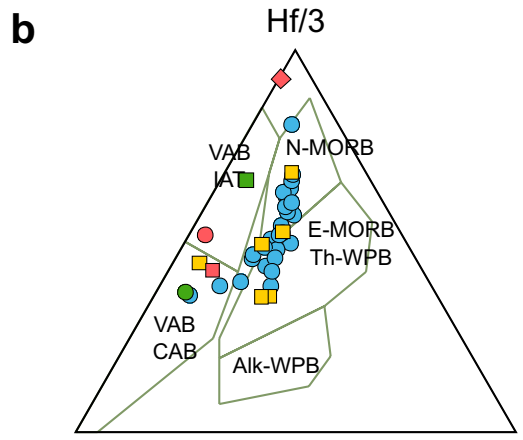

Th

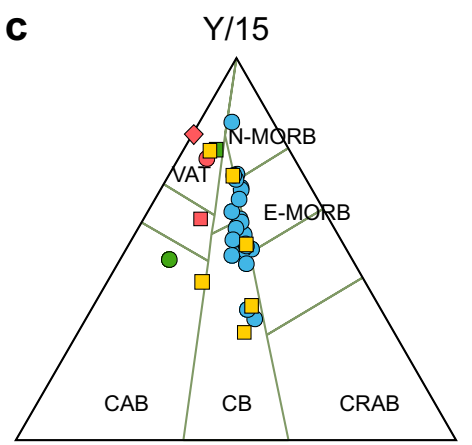

$\mathrm{La} / 10$

$\mathrm{Nb} / 8$
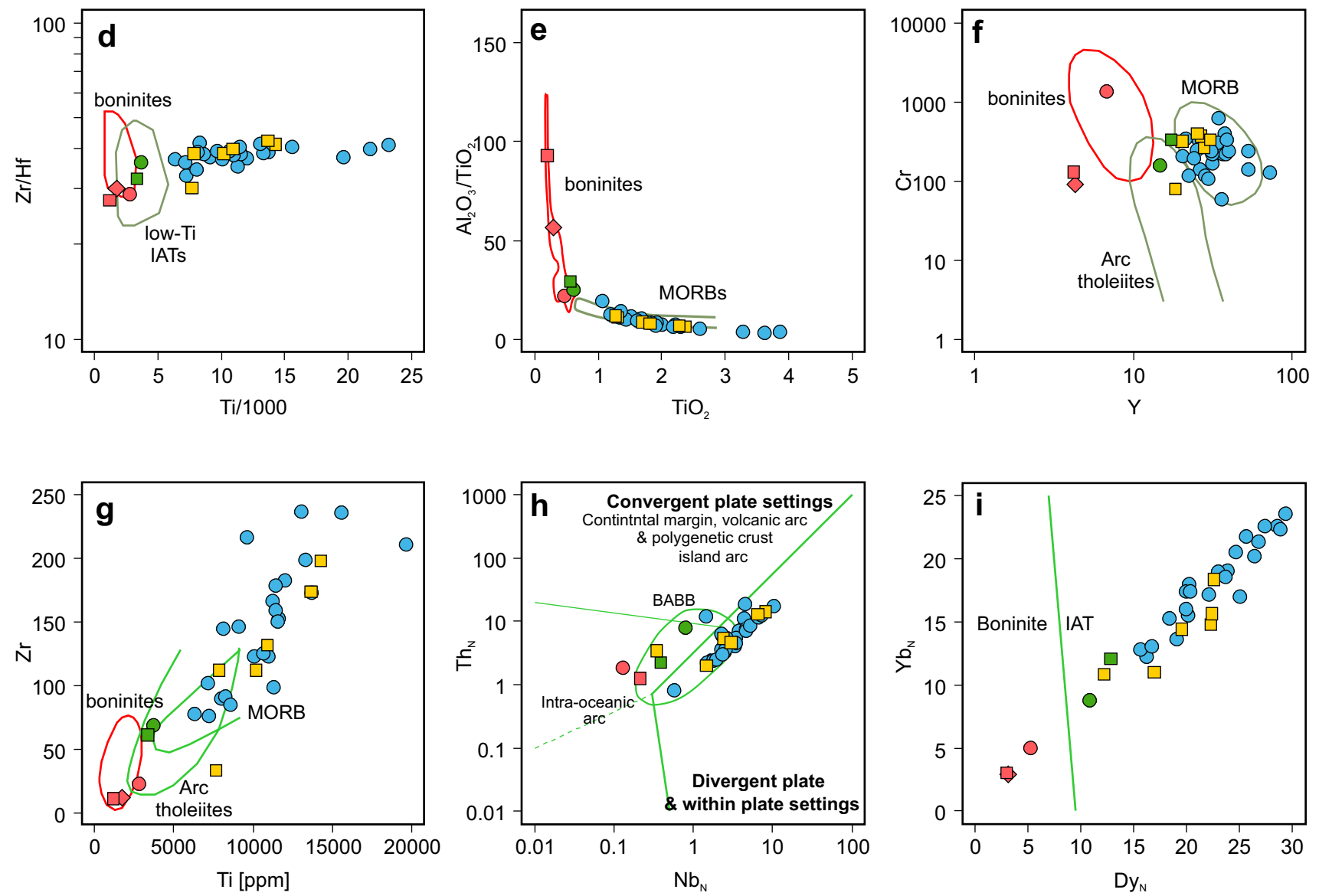

Fig. 4 Discriminant diagrams for the metabasites of the Nové Město and Zábřeh Units. a Nb-Zr-Y (Meschede 1986). b Hf-Th-Nb (Wood 1980). c Y-La-Nb (Cabanis and Lecolle 1989). d Zr/Hf vs Ti (boninite and low-Ti IAT fields after Escuder-Viruete et al. 2011). e $\mathrm{Al}_{2} \mathrm{O}_{3}$ / $\mathrm{TiO}_{2}$ vs $\mathrm{TiO}_{2}$ (Hickey and Frey 1982). f Cr vs Y (Dilek et al. 2007). g Zr vs Ti (Dilek and Furnes 2009). h $\mathrm{Th}_{\mathrm{N}}$ vs $\mathrm{Nb}_{\mathrm{N}}$ and $\mathbf{i} \mathrm{Yb}_{\mathrm{N}}$ vs Dy $_{\mathrm{N}}$ (Saccani 2015); subscript $N$ stands for composition normalized to N-MORB (values from Sun and McDonough 1989). Alk-WPB alka-

line within-plate basalts, $C A B$ calk-alkaline basalts, $C B$ continental flood basalts, $C R A B$ continental rift alkaline basalts, $E-M O R B$ enriched MORB, IAB island arc basalts, IAT island arc tholeiites, $N$-MORB normal MORB, OIB ocean island basalts, $P$-MORB plume MORB, VAT volcanic arc tholeiites, $V A B$ volcanic arc basalts, WPB within-plate basalts, WPT within-plate tholeiites, Th-WPB tholeiitic within-plate basalts. Symbols as in Fig. 2

mildly alkaline metabasites may imply a garnet-bearing source. An evident positive Eu anomaly (Eu/Eu* 1.04-1.12, aver. $1.09 \pm 0.03$ ) attests to some minor plagioclase accumulation in the fractionated mineral assemblage. The Zábřeh

metabasites display considerable variation in depletion in $\mathrm{Nb}$ relative to $\mathrm{La}$ and $\mathrm{Th}(\mathrm{Th} / \mathrm{Nb}=0.07-0.12$ up to 0.30 , even 0.51). On the N-MORB-normalized plots (Fig. 3d), these rocks mostly display patterns transitional between 


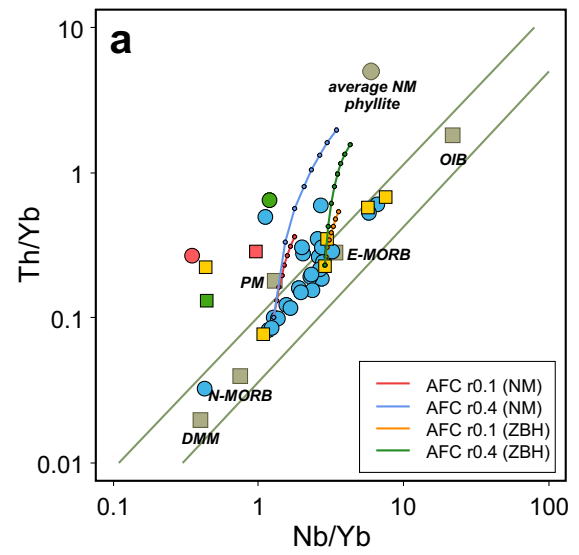

Fig. 5 a $\mathrm{Th} / \mathrm{Yb}$ versus $\mathrm{Nb} / \mathrm{Yb}$ diagram (Pearce and Peate 1995). Heavy diagonal lines of constant $\mathrm{Th} / \mathrm{Nb}$ denote the array of basalts from non-subduction settings derived from enriched- (e.g., OIB) or depleted mantle (e.g., MORB) sources. The plot shows assimilationfractional crystallisation trajectories (AFC, De Paolo 1981; partition coefficients from compilation of Ersoy and Helvaci 2010) modeled for the least-fractionated samples of the Nové Město- (LKL3 - NM) and Zábřeh Units (ZBH13 - ZBH). The mean composition of the Nové Město (NM) phyllites from Maliszewski and Ilnicki (2019). Modal composition of fractionating assemblage calculated using the

E-MORB and OIB, consistent with their elemental ratios, i.e., $\mathrm{Ti} / \mathrm{V}=37-58, \mathrm{Zr} / \mathrm{Nb}=10-33, \mathrm{Zr} / \mathrm{Y}=3.70-7.44, \mathrm{Nb} /$ $\mathrm{Yb}=1.09-7.57, \mathrm{La} / \mathrm{Nb}=1.01-2.14$. The strong- to moderate-radiogenic $\mathrm{Nd}$ isotope composition and values of $\varepsilon \mathrm{Nd}_{540}$ ranging from +7.6 to +1.9 point to the variable involvement of a non-radiogenic, presumably crustal component. Though sample $\mathrm{ZBH} 3$ has a strong negative $\varepsilon \mathrm{Nd}_{540}$ of -4.7 , its trace-element characteristics are intermediate between those of E-MORB and OIB ([La/Yb]CN $=4.60,[\mathrm{La} / \mathrm{Sm}]$ $\mathrm{CN}=1.68$, with evident $\mathrm{Zr}-\mathrm{Hf}$, $\mathrm{Ti}, \mathrm{Y}$ and $\mathrm{Nb}$ negative anomalies.

Like the boninitic-type basalts from the Nové Město Unit, sample ZBH12 is strongly depleted in incompatible elements relative to N-MORB (LREE $=\sim 0.32$ to $0.56 \times \mathrm{N}-\mathrm{MORB}$ and HREE $=\sim 0.13$ to $0.17 \times \mathrm{N}-\mathrm{MORB})$ and distinct negative $\mathrm{Nb}, \mathrm{Zr}$ and $\mathrm{Ti}$ anomalies (Fig. 3f). Its exceptional composition among the Zábřeh metabasites is man2ifested by the low $\mathrm{TiO}_{2}$ content $(0.2 \mathrm{wt} \%), \Sigma \mathrm{REE}=10 \mathrm{ppm},[\mathrm{Tb} / \mathrm{Yb}]_{\mathrm{CN}}=0.79$ and $\mathrm{Ti} / \mathrm{V}=6$ and by the high $\mathrm{Mg \#}(74)$ reflecting its primitive nature (Figs. $\mathrm{b}$ and $\mathrm{S} 1$ ). The $\mathrm{Nd}$ isotopic composition is non-radiogenic with an $\varepsilon \mathrm{Nd}_{540}$ value of - 2.9. Sample ZBH4 with its $\mathrm{TiO}_{2}$ content $(0.56 \mathrm{wt} \%), \mathrm{Mg} \#(69)$, low $\Sigma$ REE (29 ppm), Ti/V (18), $\mathrm{Zr} / \mathrm{Nb}(68)$ and $\mathrm{Th} / \mathrm{Nb}(0.30)$ shows depletion in incompatible elements, but is characterized by higher abundances of LREE at $\sim 0.80$ to $1.00 \times \mathrm{N}-\mathrm{MORB}$ and HREE at $\sim 0.63$ to $0.70 \times$ N-MORB (Fig. 3) than sample ZBH12. The time-integrated depletion of its mantle source is documented by a $\varepsilon \mathrm{Nd}_{540}$ value of +7.1 , and a flat $\mathrm{N}$-MORB-normalized profile with evident negative $\mathrm{Nb}$ and program rhyolite-MELTS v.1.0.x, (Gualda et al. 2012; Ghiorso and Gualda 2015) assuming anhydrous conditions, $\mathrm{fo}_{2}=\mathrm{QFM}$ at $1 \mathrm{kbar}$. b $\mathrm{Nb} / \mathrm{Y}$ vs $\mathrm{Zr} / \mathrm{Y}$ diagram. The $\Delta \mathrm{Nb}=0$ line separating enriched (E-MORB, OIB) from depleted (N-MORB, arc-type) sources after Fitton (2007). c $\mathrm{TiO}_{2} / \mathrm{Yb}$ vs $\mathrm{Nb} / \mathrm{Yb}$ diagram of Pearce (2008) with OIB (deep melting array) and N-MORB (shallow melting array). Dashed line separates alkaline- (Alk) and tholeiitic (Tho) compositions. The OIB, E-MORB and N-MORB values are from Sun and McDonough (1989). Symbols as in Fig. 2. Further explanation in text

Ti anomalies (Fig. 3f) is akin to that of low-Ti tholeiite of island arc affinity (Fig. 4).

\section{Petrogenetic interpretation}

The concentrations of major- and trace elements and the inter-elemental relationships outlined above divide the metabasites into two main groups, namely, (1) variably enriched tholeiites and (2) boninite-type metabasalts. These two groups are accompanied by rare low-Ti tholeiites with geochemical characteristics intermediate between the two (Figs. 3 and 4). Moreover, the data clearly show that, in the Nové Město and Zábřeh Units, neither of the two groups show any significant differences in composition. Thus, in the following discussion, the tholeiitic- and boninitic-group rocks from both units will be interpreted jointly and, further on in the text, referred to as the meta-tholeiites and the metaboninites, respectively.

Metabasites in both units underwent extensive metamorphism up to amphibolite facies conditions at medium pressures (Mazur et al. 2005; Chopin et al. 2012; Ilnicki 2013). Under such conditions, some major elements ( $\mathrm{Si}, \mathrm{Na}, \mathrm{K}, \mathrm{Ca}$ ) and trace elements $(\mathrm{Rb}, \mathrm{Cs}, \mathrm{Sr}, \mathrm{Ba}, \mathrm{U}, \mathrm{Pb})$ may well have been mobilized. Dispersion of points for some of these elements on Figures S1 and S2, and of LOI values (Table S1), confirm their mobility under post-solidus conditions. In contrast, the presumed immobile REE and HFSE (e.g., Winchester and Floyd 1977; Pearce 2014) show positive and tight trends (Figs S2 and S3) indicating that their original- or 
near-original magmatic concentrations have been retained. Hence, the following discussion and petrogenetic interpretation will rely on REE and HFSE in the main.

\section{Effects of crustal contamination}

The Nové Město and Zábřeh metabasites were emplaced into a sedimentary series comprising phyllites, metagreywackes and paragneisses. Despite their considerable volume, the mafic magmas could have been subject to contamination. When melts are derived from a depleted mantle source, they may be more susceptible to such (e.g., Pearce 2008). Thus, before any discussion on melt source and generation, the possible influence of contamination will be evaluated. Specifically, contamination by continental crust leads to higher concentrations of $\mathrm{Th}$ and to elevated values of $\mathrm{Th} / \mathrm{Yb}$ (e.g., Wilson 1993) and especially $\mathrm{Th} / \mathrm{Nb}$ (e.g., Pin and Paquette 1997). Consequently, magma compositions are displaced above the diagonal MORB-OIB mantle array on the Th/Yb $\mathrm{vs} \mathrm{Nb} / \mathrm{Yb}$ plot, especially when subducted crust releases fluids or melts into the mantle (Pearce 2008, 2014). However, the assimilation of crustal rocks produces trends that may be diagonal and oblique to the mantle array, curved and less steep than those stemming from subduction addition alone (see Fig. 5 in Pearce 2008).

The negative $\mathrm{Nb}$, Ti anomalies of the meta-tholeiites (Fig. 3) and the $\mathrm{Th} / \mathrm{Nb}$ of $<0.22$ of sample SKV12 or even 0.44 of sample SKV19 imply some crustal contribution to the magmas, as is also suggested by low value of $\varepsilon \mathrm{Nd}_{540}(+3.5)$ for the latter sample. However, the majority of the meta-tholeiites plot within the diagonal mantle array (Fig. 5a), while their $\mathrm{Th} / \mathrm{Nb}(0.07-0.12)$ and $\mathrm{La} / \mathrm{Nb}$ (0.94-1.33) values are confined to a narrow range between and close to N-MORB or OIB values $(\mathrm{Th} / \mathrm{Nb} 0.05$ and 0.08 ; $\mathrm{La} / \mathrm{Nb} 0.77$ and 1.07, respectively; Sun and McDonough 1989). The systematics of $\varepsilon \mathrm{Nd}_{540} \mathrm{vs} \mathrm{Th} / \mathrm{Nb}$ or vs $\mathrm{La} / \mathrm{Nb}$ (not shown) preclude significant assimilation of crust material. The majority of the meta-tholeiite samples define a tightand nearly vertical trend more likely consistent with mantle source heterogeneity rather than any substantial involvement of an old crustal component with elevated $\mathrm{Th} / \mathrm{Nb}$ and low $\varepsilon N d$ (i.e., low secular Sm/Nd; Pin and Waldhausrova 2007). Although some samples plot randomly at various distances from the mantle array and towards higher values $\mathrm{Th} / \mathrm{Yb}$ on the $\mathrm{Th} / \mathrm{Yb}$ vs Nb/Yb plot (Fig. 5a), they do not define any coherent trend, either vertical or diagonal. Moreover, they do not follow the curves calculated for assimilation-fractional crystallization (AFC; DePaolo 1981). The AFC model presupposes assimilation of phyllites and metagreywackes of the Nové Město Unit (data from Maliszewski and Ilnicki 2019) by the most primitive Nové Město- (sample LKL13; $\mathrm{Mg \#}=66 ; \mathrm{Zr}=90 \mathrm{ppm})$ and Zábřeh magmas (ZBH13; $\mathrm{Mg} \#=68 ; \mathrm{Zr}=132 \mathrm{ppm})$. For each sample, the modal composition of the fractionated phases was obtained using the MELTS program (rhyolite-MELTS v.1.0.x; Gualda et al. 2012; Ghiorso and Gualda 2015) for isobaric, low-pressure fractionation at $1 \mathrm{kbar}$ and at temperatures ranging from liquidus down to when $<10 \%$ liquid remained (Fig. 5a). Regardless of the assumed assimilation/crystallization ratio (i.e., $r$ values of 0.1 and 0.4 for low- and high crustal input, respectively), the calculated trajectories do not account for the dispersion of points on the plots. Even though some samples lie close to the curves, the models suggest either insignificant contamination, i.e., low $r$ values, or unreasonably high values of melt fractionation $(\sim 70-80 \%)$ that would result in fractionated melts much richer in silica than is seen (Table 1S). Thus, it may be concluded that the degree of contamination by continental crust had little effect on tholeiite-magma compositions. Subduction-related metasomatism seems to offer a better explanation for the geochemical character of the meta-tholeiite protoliths as the meta-boninites and low-Ti meta-tholeiites have particularly elevated $\mathrm{Th} / \mathrm{Yb}$ implying incorporation of subduction-derived components into their sources.

\section{Subduction-related contribution}

Mafic rocks from intra-oceanic settings are less prone to substantial crustal contamination. As discrimination diagrams show (Fig. 4), the rocks studied here have compositional affinities to arc-related basalts or form continuous trends from variably enriched or depleted N-MORB-type tholeiites to island arc tholeiites or to boninites. It is proposed, therefore, that several features observed in the meta-tholeiites and meta-boninites, e.g., enrichment in Th and LREE and depletion in $\mathrm{Nb}$ and $\mathrm{Ti}$, point to the significant influence of subduction zone activity. Island arc-related magmas and lavas may record contributions from a variety of subducted material, e.g., fresh- or hydrothermally altered oceanic crust and subducted sediments, affecting their variably enriched or depleted mantle wedge (Hawkesworth et al. 1993, 1997). Thus, the degree of the subduction zone involvement in the meta-tholeiites and meta-boninites merits examination.

The most conspicuous feature of arc magmas is their relative depletion in HFSE, notably $\mathrm{Nb}$ and $\mathrm{Ta}$ but also $\mathrm{Zr}$, Hf, Ti and Y, coupled with enrichment in LILE and LREE-MREE (e.g., Pearce and Parkinson 1993; Pearce et al. 1995). Studies on incompatible element behavior have shown that $\mathrm{Nb}$, $\mathrm{Ta}, \mathrm{Zr}, \mathrm{Hf}, \mathrm{Ti}$ and $\mathrm{Y}$ are particularly resistant to mobilization by aqueous fluids released and circulating in supra-subduction zone realms (e.g., Pearce and Peate 1995). In contrast, LILE, Th and REE, particularly LREE, are readily mobilized and may contribute to variously metasomatized potential sources of arc-related magmas (e.g., Brennan et al. 1995). Otherwise, mantle-wedge material would be chemically and isotopically similar to depleted MORB-type mantle, as is 
often observed in back-arc basin basalts (Hawkesworth et al. 1993; 1997).

\section{Assessment of subduction input}

Based on these assumptions, which comply with the concept of conservative (HFSE, HREE and compatible elements $\mathrm{Cr}$, $\mathrm{Ni}, \mathrm{Co}, \mathrm{V}, \mathrm{Sc}$ ) and non-conservative (LILE, LREE-MREE) elements of Pearce and Peate (1995), the relative contributions from the subduction zone and from the mantle wedge to the basic magmas may be assessed. Particularly useful in this context is the "baseline approach" of Pearce and Parkinson (1993) which relies on the construction of a line connecting the conservative, mantle-derived elements of an individual sample in the N-MORB-normalized diagrams. With extrapolation and interpolation, the line visualizes the primary mantle composition prior to metasomatic modification, while the area above the baseline reflects the slab contribution of a given element. Differences in the pattern of the baseline for the samples of the studied suite reflect a heterogeneous distribution and input of the subducted slabderived components (Fig. S4) which, in the meta-tholeiites, varies from barely perceptible (e.g., samples LKL1, LKL13, NHR1, KNO2, KNO3, ZBH6, ZBH13) and weak (e.g., LKL15, SKV1, SKV19, LKL18.1, ZBH2, ZBH10) to obvious (e.g., NHR10, OLE1, LKL3, ZBH3). In the low-Ti metatholeiites (ZBH4, KNO4) and in the meta-boninites (LKL7, SKV15, ZBH12), the addition is significant, though varied. Moreover, the bivariate Yb-normalized diagrams (Fig. S6) show that the subduction contribution reaches $\sim 70-90 \%$ of the $\mathrm{Th}, \sim 50-70 \%$ of the $\mathrm{La}$ and $>\sim 25 \%$ of the Nd. The mantle source was affected by components enriched in LREE ( \pm MREE) and LILE (Th), but not HFSE.

\section{Slab-derived melts vs fluids}

Subducted slab and overlying sediments are commonly considered principal sources of melts and fluids which, liberated, combine and flux the mantle wedge and enrich it (e.g., Hawkesworth et al. 1993, 1997; Elliott 2003). The composition and specific trace element- and isotopic signatures of a metasomatizing agent depend heavily on its physical state, mantle-wedge conditions and, predominantly, the type of entity that released it (Hawkesworth et al. 1993).

Melts generated from subducted, comparatively young, ensimatic crust, i.e., fresh and sediment-poor, relatively hot MORB-type slab, should retain highly radiogenic Nd signatures. Interacting with the DMM-type mantle, they would not significantly alter its isotopic composition. Hence, melts produced from such sources that reveal significant addition of subduction-derived component in their incompatibleelement composition, are deemed to preserve their original, positive $\varepsilon \mathrm{Nd}$ values. In fact, the samples (meta-tholeiites
LKL16 + 4.1, LKL7 + 2.9, ZBH3 - 4.7; meta-boninites LKL7 + 2.9, ZBH12 - 2.9) with a distinct subduction component have lowered- or even negative values of $\varepsilon \mathrm{Nd}$, implying an input from material less radiogenic than juvenile crust on a time-integrated basis. In contrast, there are also samples (meta-tholeiite LKL3 + 6.2; low-Ti meta-tholeiite ZBH4+7.1; meta-boninite SKV15 +6.7) which display similar degrees of subduction-derived addition to the source as indicated by their baseline layout (Fig. S4), but which have strong radiogenic $\mathrm{Nd}$ compositions indicating the influence of melts derived from relatively young MORB-type slab. During fusion of the slab, however, the incompatible elements (REE, HFSE) are likely to fractionate appreciably. Consequently, magmas produced from mantle wedge metasomatized by slab-melt should yield high $\mathrm{La} / \mathrm{Yb}, \mathrm{Nb} / \mathrm{Zr}$ and $\mathrm{Nb} / \mathrm{Y}$ (e.g., Stolz et al. 1996; Hawkesworth et al. 1997). The highly radiogenic signatures of samples LKL3, ZBH4 and SKV15 contrast with their low $\mathrm{Nb} / \mathrm{Y}(<0.05), \mathrm{Nb} / \mathrm{Zr}$ (0.01-0.02), $\mathrm{La} / \mathrm{Yb}(0.69-1.40)$ and seem to preclude such an addition to their source. An alternative plausible explanation, however, would envisage hydrous fluids released from subducted juvenile crust fluxing the mantle source. Such a process is not likely to significantly disturb the $\mathrm{Nd}$ isotopic signatures of essentially DMM-type mantle wedge (e.g., Crawford et al. 1989; Hawkesworth et al. 1993).

The overall positive trend observed in the $\varepsilon \mathrm{Nd}_{540}$ $\mathrm{vs}^{147} \mathrm{Sm} /{ }^{144} \mathrm{Nd}$ plot (Fig. 6b) suggests that the prevailing component in the metasomatizing material was less radiogenic, attesting to a predominant role for melts or fluids released from crust-derived sediments. Melts produced at the expense of subducted sediment are much more effective than fluids in extracting LREE and HFSE (e.g., Brennan et al. 1995; Elliott 2003; Johnson and Plank 2000). Moreover, in contrast to DMM (Th $0.0079 \mathrm{ppm}, \mathrm{Th} / \mathrm{Nd} 0.0136$; Workman and Hart 2005) subducted sediments are on average enriched in Th $(8.1 \mathrm{ppm}, \mathrm{Th} / \mathrm{Nd} 0.29$ in global subducting sediment; GLOSS-II, Plank 2014). During melting of the subducted sediments and due to differences in incompatibility, the liquids produced are preferentially enriched in Th relative to $\mathrm{Nd}$ or $\mathrm{Zr}$ and in La relative to $\mathrm{Sm}$ (e.g., Johnson and Plank 2000). Thus, variation in $\mathrm{Th} / \mathrm{Nd}$, Th/ $\mathrm{Zr}$ or $\mathrm{Th} / \mathrm{Nb}$ vs $[\mathrm{La} / \mathrm{Sm}]_{\mathrm{CN}}$ may serve as useful discriminators of influx into the mantle wedge of melts derived from subducted sediment. These melts are also clearly discerned because hydrous fluids released from the slab usually have lower values of $\mathrm{Th} / \mathrm{Nd}(<0.15$ in fluids compared to $>0.25$ in melts; Wolkl et al. 2018). Furthermore, if the subducted sediments are significantly less radiogenic than the DMM (e.g., Zindler and Hart 1986), the trends resulting from the influx of sediment-derived melts into mantle wedge should be negative on $\varepsilon \mathrm{Nd}$ vs $\mathrm{Th} / \mathrm{Nd}$ or $\mathrm{Th} / \mathrm{Zr}$ plots. The studied samples have $\mathrm{Th} / \mathrm{Nd}$ values confined to narrow range of 0.01-0.0.09 and mostly follow positive- and steep trends on 

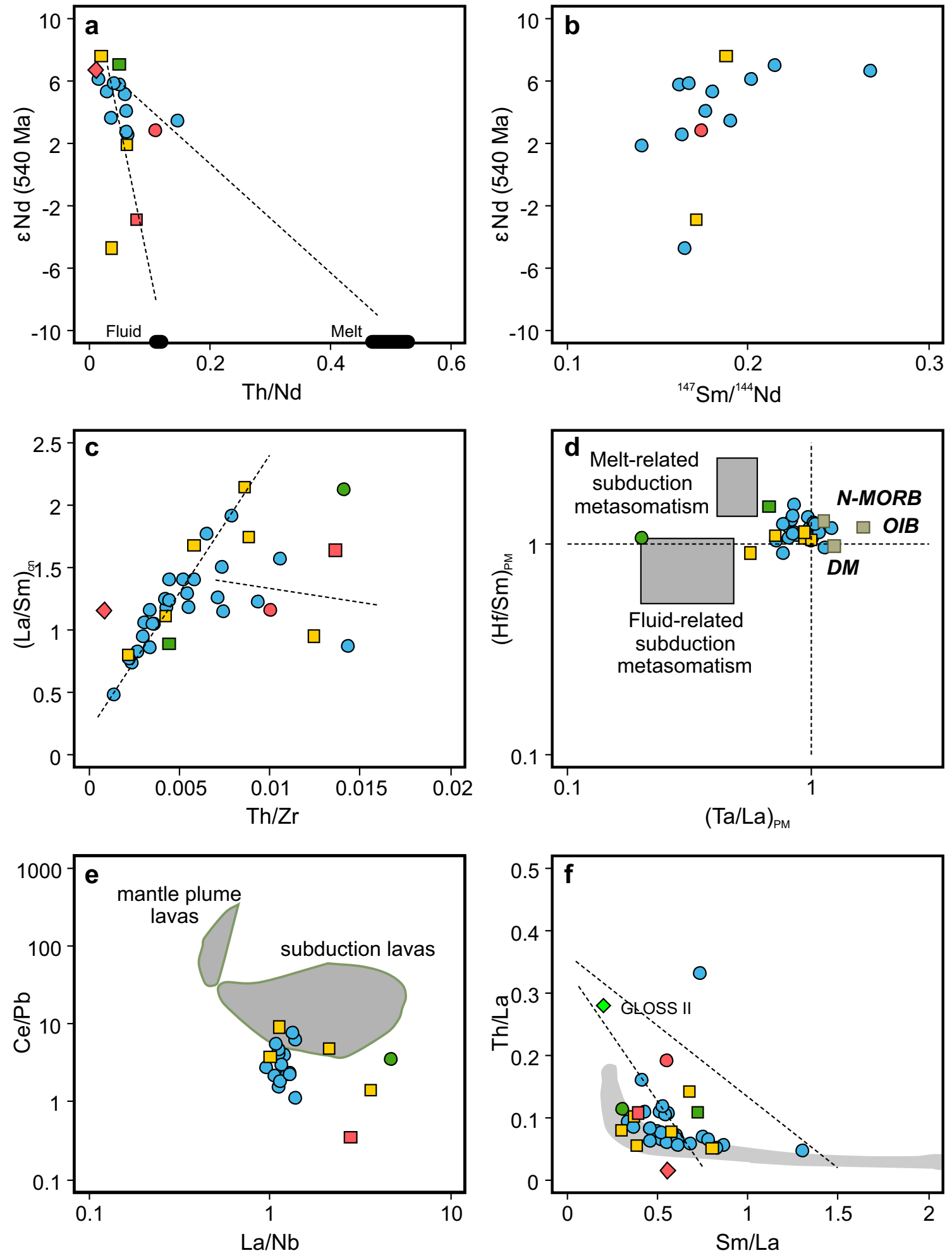

Fig. 6 Variation diagrams: a $\varepsilon \mathrm{Nd}_{540}$ vs $\mathrm{Th} / \mathrm{Nd}$. The $\mathrm{Th} / \mathrm{Nd}$ values for fluids and melts from Woelkl et al. (2018). b $\varepsilon \mathrm{Nd}_{540} \mathrm{vs}{ }^{147} \mathrm{Sm} /{ }^{144} \mathrm{Nd}$. c $[\mathrm{La} / \mathrm{Sm}]_{\mathrm{CN}}$ vs $\mathrm{Th} / \mathrm{Zr}$. d $[\mathrm{Hf} / \mathrm{Sm}]_{\mathrm{PM}}$ vs $[\mathrm{Ta} / \mathrm{La}]_{\mathrm{PM}}$. Fields after $\mathrm{He}$ et al. (2018), N-MORB and OIB data as in Fig. 5. Subscripts PM and $\mathrm{CN}$ stand for data normalized to, respectively, primitive mantle and chondrite (values from Sun and McDonough 1989). e Ce/Pb vs La/

Nd. Fields after Kumar and Rathna (2008). f Th/La vs Sm/La. Mantle array from Plank (2005), global subducting sediment, GLOSS-II from Plank (2014). The two dashed lines are regression lines for samples most marked by sediment-derived input. Symbols as in Fig. 2. Further explanation in text 
the $[\mathrm{La} / \mathrm{Sm}]_{\mathrm{CN}}$ vs $\mathrm{Th} / \mathrm{Zr}$ or $\varepsilon \mathrm{Nd}$ vs $\mathrm{Th} / \mathrm{Nd}$ plots (Fig. 6a, c). However, there is a clear horizontal dispersion of the points (Fig. 6a, c) because the meta-boninites (LKL7, ZBH12), the low-Ti meta-tholeiite (KNO4) and some meta-tholeiites (e.g., OLE2, LKL1, LKL4, LKL16, SKV12, SKV19, ZBH8) show higher values of $\mathrm{Th} / \mathrm{Nd}(<0.14)$ and $\mathrm{Th} / \mathrm{Zr}(<0.014)$. In addition, there is a very good positive correlation between $\mathrm{Th} / \mathrm{Nd}$ and $\mathrm{Th} / \mathrm{Zr}$ (not shown). These features all coherently corroborate enrichment of the mantle source with sedimentderived melt. Likewise, variation in $[\mathrm{Hf} / \mathrm{Sm}]_{\mathrm{PM}}$ vs $[\mathrm{Ta} / \mathrm{La}]_{\mathrm{PM}}$ points to melt-induced metasomatism as the data mostly follow a trend (Fig. 6d) consistent with melt effectively extracting HFSE and subsequently fluxing the mantle sources. This conclusion is further supported by some negative correlation between $\mathrm{Nd}$ isotope composition and $\mathrm{Th} / \mathrm{Nd}$ or $\mathrm{Th} / \mathrm{Zr}$ (Fig. 6a). Such an effect is expected when melt derived from non-radiogenic sediment is added to a DMM-type mantle source (e.g., Woelkl et al. 2018). Nevertheless, some samples suggest that they either lacked such a component or that input was limited, introducing the possibility of hydrous fluids being a further potential source of subduction-driven metasomatic modification of their mantle sources.

Fluid-related metasomatism of mantle sources may be recognized due to the selective ability of hydrous solutions to extract and transport predominantly LILE ( $\mathrm{Rb}, \mathrm{Ba}, \mathrm{Sr}, \mathrm{Cs}$, $\mathrm{Th}, \mathrm{Pb}, \mathrm{U}, \mathrm{Na}, \mathrm{K}$ ) and, to a lesser extent, LREE-MREE (La, $\mathrm{Ce}, \mathrm{Nd}, \mathrm{Sm}, \mathrm{Eu})$ while not affecting essentially immobile HFSE (Nb, Ta, Zr, Hf, Ti, Y; e.g., Pearce and Parkinson 1993; Brennan et al. 1995; Peace and Peate 1995). Thus, fluxed portions of mantle, and of arc-related magmas produced from them, will have LILE/REE or LILE/HFSE distinctly higher than mantle metasomatized by sediment melt. Variations in $\mathrm{Ba} / \mathrm{Th}, \mathrm{Sr} / \mathrm{Nd}, \mathrm{Ce} / \mathrm{Pb}$ and $\mathrm{Nb} / \mathrm{U}$, especially, serve as very sensitive tracers of aqueous fluid involvement (e.g., Hawkesworth et al. 1997; Elliott 2003). Low $\mathrm{Ce} / \mathrm{Pb}$ and $\mathrm{Nb} / \mathrm{U}$, well below the N-MORB values of $\sim 25$ and $\sim 50$, respectively (Sun and McDonough 1989), commonly signal a substantial addition of $\mathrm{Pb}$ and $\mathrm{U}$ where mantle wedge is fluxed by components with high water contents (e.g., Escrig et al. 2012). In the rocks studied, values of $\mathrm{Nb} / \mathrm{U}$ (44.2-1.8) and $\mathrm{Ce} / \mathrm{Pb}(9.1-0.4$; Fig. 6e) indicate variable though ubiquitous input of hydrous solutions expelled from the downgoing slab. Interestingly, the data from some rocks (e.g., SKV6, SKV17, NHR10, ZBH1, ZBH3) imply that their respective mantle sources were metasomatized solely by fluids while others (e.g., tholiites LKL16, SKV12, SKV19, ZBH8; low-Ti meta-tholeiite KNO4; meta-boninite ZBH12) reveal input from both sediment melts and fluids. A weak positive correlation between these ratios and $\mathrm{Zr} / \mathrm{Y}$ suggests an augmented fluid input into more depleted mantle sources. It must be noted, however, that the applicability of LILE-based tracers is limited in metamorphic rocks as LILE are potentially mobile under low-grade metamorphism (see above). Nevertheless, the tight positive trends on the $[\mathrm{La} / \mathrm{Sm}]_{\mathrm{CN}} \mathrm{vs} \mathrm{Th} / \mathrm{Zr}$ plot (Fig. 6c) and the nearly vertical trend on the $\varepsilon \mathrm{Nd}_{540}$ vs $\mathrm{Th} / \mathrm{Nd}$ plot (Fig. 6a) are in line with the inferences drawn from the variations in $\mathrm{Ce} / \mathrm{Pb}$ or $\mathrm{Nb} / \mathrm{U}$. Moreover, the degree of spread of points towards decreasing values of $[\mathrm{Hf} / \mathrm{Sm}]_{\mathrm{PM}}$ on the $[\mathrm{Hf} / \mathrm{Sm}]_{\mathrm{PM}}$ vs $[\mathrm{Ta} / \mathrm{La}]_{\mathrm{PM}}$ plot confirms that mantle wedge sources could have been modified by hydrous fluids (Fig. 6d).

The chemistry of the subducted sediment may be explored using the Th/La vs Sm/La plot (Fig. 6f). The approach assumes that excess $\mathrm{Th}$, and consequently, high $\mathrm{Th} / \mathrm{La}$ in arc magmas are inherited from subducted sediments which usually have low $\mathrm{Sm} / \mathrm{La}(\sim 0.20$, Plank 2014). Mantle-derived basalts (N- and E-MORB, OIB) because of their low $\mathrm{Th} / \mathrm{La}$ but varied $\mathrm{Sm} / \mathrm{La}$ reflecting source depletion, plot as a nearly horizontal array (Fig. 6f). Depending on the proportions of sediment and mantle involved, both $\mathrm{Th} /$ $\mathrm{La}$ and $\mathrm{Sm} / \mathrm{La}$ from arc basalts create linear mixing trends anchored at bulk-sediment composition and pristine mantle source. The samples of meta-tholeiite and meta-boninite marked by sediment-derived input (as melt or fluid) to their respective sources define two trends which, when unmixed, point to sediment with a $\mathrm{Th} / \mathrm{La}$ of $\sim 0.27-0.32$, very close to the value of global subducting sediment, GLOSS-II ( 0.28 ; Plank 2014). As argued by Plank (2005), this value may be the same as that of the local trench sediment subsequently recycled into the arc. Additionally, the regressed line intersects the mantle array and indicates melts with $\mathrm{Sm} / \mathrm{La}$ from $0.7-0.8$ to $\sim 1.5$. Provided that N-MORB and E-MORB values range from $\sim 1.0$ to $\sim 0.4$, respectively (Sun and McDonough 1989), it may be inferred that the tapped sources for protoliths of both the meta-tholeiites and meta-boninites span the range from slightly enriched- to noticeably depleted mantle (section "Melt sources").

\section{Melt sources}

The activity of a subduction zone affects and to various degrees controls the budget of LREE, MREE and LILE in the mantle sources of mafic arc magmas. This places constraints on incompatible- and compatible trace elementbased assessments of mantle sources and melt-generation processes. The trace element- and isotope compositions of the meta-tholeiites and the meta-boninites provide compelling evidence that a proportion of LREE, MREE (and presumably LILE) was extracted in the form of melts or fluids from down-going slab and supplied to their respective mantle sources. In contrast, scrutiny of HREE and HFSE showed that these may be, to a large degree, deemed conservative and, thus, that their abundances can provide important clues concerning mantle-wedge composition prior to subductionrelated metasomatism. Several useful indicators based on abundances and proportions of HFSE (e.g., Zr, Ti, Nb, Y) 
and HREE (e.g., Tb, Yb) have been devised with reference to arc-related environments. Being insensitive to the degree of fractional crystallization, these proxies (e.g., $\mathrm{Nb} / \mathrm{Yb}$, $\mathrm{Zr} / \mathrm{Y}, \mathrm{Zr} / \mathrm{Nb}, \mathrm{Nb} / \mathrm{Y}$ and the $\Delta \mathrm{Nd}$ parameter of Fitton et al. 1997) efficiently fingerprint source heterogeneity (enrichment or depletion), degree of partial melting or alkalinity, depth of melting or input from enriched components (e.g., Ti/Yb; Pearce and Parkinson 1993; Pearce et al. 1995; Fitton et al. 1997; Pearce and Stern 2006; Pearce 2008, 2014). Potential mantle sources, the degree of partial melting and any presence of residual phases (garnet, amphibole) can be evaluated using normalized conservative-element FMMnormalized plots, FMM being fertile MORB mantle, i.e., the global convecting upper mantle reservoir that is the source of N-MORBs (Pearce and Parkinson 1993).

\section{Nové Město and Zábřeh meta-tholeiites}

The profiles on multi-element PM- and N-MORB-normalized diagrams (Fig. 3), variation of $\mathrm{Zr} / \mathrm{Nb}$ and $\mathrm{Nb} / \mathrm{Y}$ and the distribution of samples within the mantle array on the $\mathrm{Th} /$ $\mathrm{Yb} v \mathrm{Nb} / \mathrm{Yb}$ plot (Fig. 5a), and the spread of data on $\mathrm{TiO}_{2} /$ $\mathrm{Yb} v \mathrm{Nb} / \mathrm{Yb}$ plots (Fig. 5c), suggest that the meta-tholeiite protoliths were produced from mantle regions showing variable enrichment. The enriching component was not related to subduction activity and must have been heterogeneously distributed within the predominant DMM. Thus, the parental magmas of meta-tholeiites produced from such mantle sources encompass a whole spectrum of geochemical features ranging from transitional between OIB and E-MORB and/or between E-MORB and N-MORB, and N-MORB. The marked heterogeneity of the mantle wedge is further confirmed by the varying slopes of baselines (Fig. S4) and by considerable variations in the $\Delta \mathrm{Nb}$ parameter (Fig. 5b). Fitton et al. (1997) ascribed negative $\Delta \mathrm{Nb}$ values to depleted mantle sources (N-MORB and arc type) and positive values to enriched sources (OIB and E-MORB). The $\Delta \mathrm{Nb}(-0.64$ to +0.03$)$ for the meta-tholeiites reflect the variation in the degree of source enrichment. However, despite the enrichment also indicated by other geochemical parameters (e.g., $\mathrm{Zr} / \mathrm{Nb}, \mathrm{Nb} / \mathrm{Y}$ ), the values for the meta-tholeiites remain essentially negative. Even the samples with mildly alkalineand the most enriched geochemical characteristics (KNO2, $\mathrm{KNO} 3, \mathrm{ZBH} 2, \mathrm{ZBH} 6)$ have $\Delta \mathrm{Nb}$ values ranging from -0.08 to -0.13 that indicate inherent source depletion as is corroborated by prevailing strongly to mildly radiogenic $\mathrm{Nd}$ isotope compositions (Table $2 \mathrm{~S}$ ). In contrast, the protolith of sample LKL3 $\left(\varepsilon \mathrm{Nd}_{540}+6.2\right)$ was derived from a strongly depleted source as its $\mathrm{Nb} / \mathrm{Yb}(0.42)$ is lower than that of average typical N-MORB (0.72; Sun and McDonough 1989); the LKL3 magma may have been partly derived from sources even more depleted than DMM, presumably residual after earlier melting (see section "Nové Město and Zábřeh boninites").

The diagonal scattering of points on the $\mathrm{Nb} / \mathrm{Y}$ vs $\mathrm{Zr} / \mathrm{Y}$ plot (Fig. 5b) implies variable degrees of fusion. Due to differences in incompatibility, $\mathrm{Zr} / \mathrm{Y}$ values are likely to be higher when melting is limited (Pearce and Norry 1979). High values of $\mathrm{Zr} / \mathrm{Y}$ (6.26-7.72) for the most enriched samples (KNO2, KNO4, ZBH2, ZBH6) suggest low degrees of fusion, and low $\mathrm{Zr} / \mathrm{Y}$ (1.79-2.71) for samples ZBH8 and LKL3, high degrees. However, most samples show intermediate values indicating moderate, if varied, degrees of melting. The process took place within the spinel stability field. For most samples, $[\mathrm{Tb} / \mathrm{Yb}]_{\mathrm{CN}}<1.6$ and low $\mathrm{TiO}_{2} / \mathrm{Yb}$ values point to shallow melting typical of N-MORB-type basalts (Pearce 2008; Fig. 5c). This is supported by calculated pressures $(0.7-1.8 \mathrm{GPa})$ of magma generation, implying a depth $<\sim 60 \mathrm{~km}$ (Lee et al. 2009; Fig. S5). However, [Tb/ $\mathrm{Yb}]_{\mathrm{CN}}$ values (1.66-1.81) for the mildly alkaline samples and their elevated $\mathrm{TiO}_{2} / \mathrm{Yb}$ (Fig. 5c) coupled with the highest calculated pressure (2.4 GPa for OLE1; $80 \mathrm{~km}$ ) suggest somewhat greater depths corresponding to the spinel-garnet transitional zone. However, apparent deeper levels of melt formation may, in fact, reflect of a more complex path of mantle source enrichment.

The inferences above are confirmed by the FMM-normalized profiles for the meta-tholeiites (Fig. 7). Their patterns, predominantly with elemental abundances $\mathrm{VHI} \gg \mathrm{HI} \geq \mathrm{MI}$ (VHI-very highly incompatible, HI-highly incompatible, MI-moderately incompatible), are consistent with enriched- to unenriched fertile sources (with respect to FMM) which underwent moderate degrees of partial melting ( 10\%). Four samples (meta-tholeiites LKL3, ZBH8 and low-Ti meta-tholeiites ZBH4 and KNO4) have patterns of $\mathrm{VHI} \geq \mathrm{HI} \geq \mathrm{MI}$ that can be attributed to moderate to high degrees of partial melting (>10\%) of unenriched FMM, or alternatively, to low degrees of melting $(<5 \%)$ of a slightly depleted residual source that had earlier lost $\sim 5 \%$ of melt. Additionally, in both types of profile, negative anomalies for $\mathrm{Y}-\mathrm{Yb}$ or Ti are absent, indicating a source devoid of residual garnet or amphibole, respectively. Lack of amphibole may imply a pristine dry lherzolitic source. However, the input from subducted slab must have included some hydration.

Whereas the origin of the depleted meta-tholeiites seems unambiguous, the enrichment of their mantle source(s) requires further examination. Hence, the least fractionated samples (LKL1, LKL12, SKV12, KNO2, ZBH2, ZBH6, $\mathrm{ZBH} 13)$ representing various degrees of enrichment, but unmodified by subduction-derived components, were compared with calculated geochemical models of melt formation (non-modal aggregated fractional melting) in the spinel stability field. The geochemical features of the meta-tholeiites rule out melting solely of primitive mantle, deemed here a model approximation of a slightly enriched 

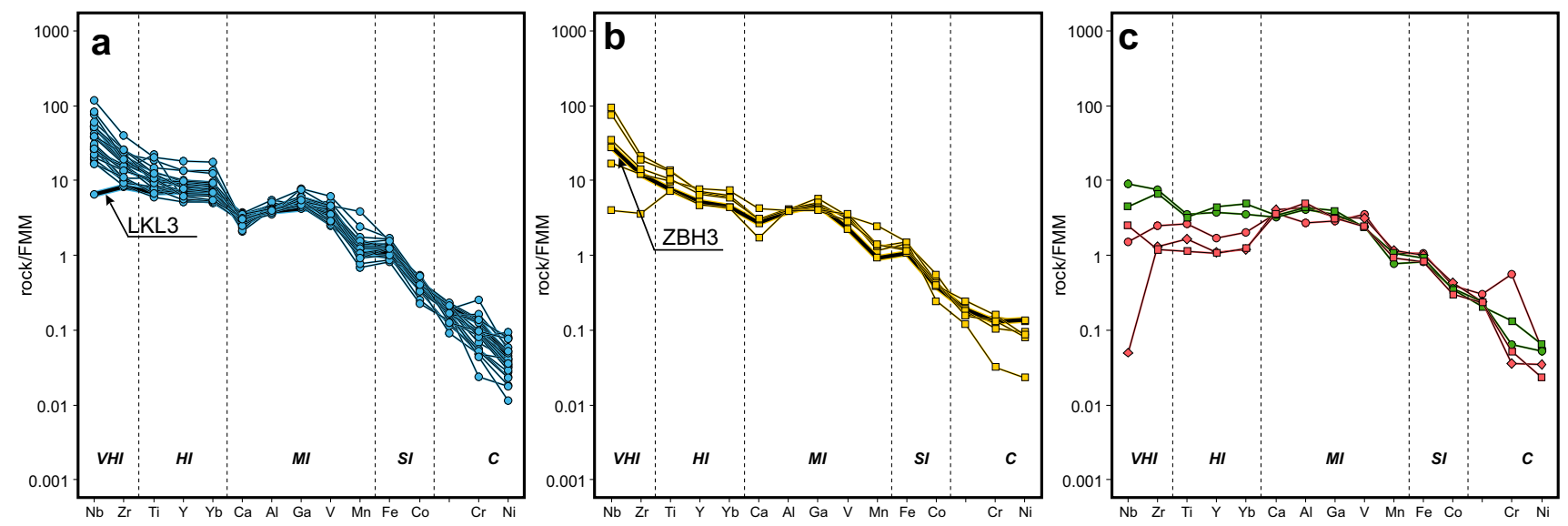

Fig. 7 FMM-normalized (FMM-fertile MORB mantle) patterns for: a meta-tholeiites from the Nové Město Unit, b meta-tholeiites from the Zábřeh Unit, c meta-boninites and low-Ti meta-tholeiites. Normalizing values and subdivisions from Pearce and Parkinson (1993)

source. Neither did low degree-melting of DMM reproduce the meta-tholeiite compositions (Fig. 8a). However, the decoupling between the enriched characteristics of the meta-tholeiites and their radiogenic $\mathrm{Nd}$ isotope compositions $\left(\mathrm{eNd}_{540}=+1.9\right.$ to +2.6$)$, reflecting long-term depletion in $\mathrm{Nd}$ relative to $\mathrm{Sm}$, suggest relatively recent enrichment of DMM by incompatible element-rich components. Thus, the calculated models assumed addition to DMM, prior to its melting, of low-degree (5\%) OIB-like alkaline melt derived from primitive mantle. The results show that mixing of $8-10 \%$ of this melt with DMM and later $~ 10-15 \%$ fusion of such a metasomatized reservoir at shallow levels reproduces the enriched meta-tholeiites. These values of partial melting lie within the range for subduction-related lavas (e.g., König et al. 2010). Furthermore, the models explain that the degree of enrichment of the meta-tholeiites strongly depends on depth of alkaline-melt formation, with their intrinsic reservoir remaining the same. The OIB-like melts derived at garnet facies could have metasomatized the source that gave rise to the mildly alkaline magmas represented by samples KNO2, KNO3, ZBH2 and ZBH6 (Fig. 8b). In turn, the mantle region that provided the magmas for the variably enriched tholeiites required an alkaline component generated at shallower levels, at spinel-garnet facies (LKL12, ZBH13; Fig. 8c) or spinel facies (LKL1, SKV12; Fig. 8d). The models appear to reconcile enriched- and depleted reservoir mixing with the shallow vs deep melt-formation depths implied by the diagonal trend on the $\mathrm{TiO}_{2} / \mathrm{Yb} v \mathrm{Nb} /$ $\mathrm{Yb}$ plot (Fig. 5c). Moreover, uneven distribution and addition of small amounts $(<10 \%)$ of an OIB-like component to a DMM source could have led to the varied Nd isotope composition of the meta-tholeiites, though the source remained essentially radiogenic. Such a component must have had an $\varepsilon \mathrm{Nd}$ lower than OIB-HIMU $(\varepsilon \mathrm{Nd}=+4$ to +6 ; Zindler and Hart 1986) to account for the $\mathrm{Nd}$ isotopic signature in the meta-tholeiites. Thus, it could be conjectured that the OIBlike ingredient was enriched mantle of EM1- or EM2 type characterized by undoubtedly negative $\varepsilon \mathrm{Nd}$ values (Zindler and Hart 1986; Hofmann 2014; Willbold and Stracke 2010). It would also explain the extremely non-radiogenic Nd isotope composition of enriched sample ZBH3 $\left(\varepsilon \mathrm{Nd}_{540}=-4.7\right)$ which nevertheless reveals a significant subduction-related input (Fig. S4). Presumably, the $\varepsilon \mathrm{Nd}_{540}$ value reflects source metasomatism induced by alkaline melt (EM1-EM2) coupled with an addition of subduction-derived material. Likewise, the presence of an EM-type component in the source may also account for the shift of magma composition above the mantle array (Pearce 2008), as observed for the mildly alkaline samples of the meta-tholeiites (Fig. S6).

\section{Nové Město and Zábřeh boninites}

The geochemical features of the meta-boninites, e.g., the low content of $\mathrm{TiO}_{2}$, HFSE-HREE abundances much lower than in N-MORBs (Fig. 3) and low $\mathrm{Nb} / \mathrm{Yb}, \mathrm{Nb} / \mathrm{Y}$ and $\mathrm{Zr} / \mathrm{Y}$ (Fig. 5) all indicate a much depleted mantle source. Likewise, the FMM-normalized profiles for the meta-boninites have patterns $\mathrm{VHI}<\mathrm{HI} \leq \mathrm{MI}$ typical of depleted sources (residual after $\sim 10-15 \%$ melting) re-enriched in VHI and denoting a high degree of melting. The lack of negative Ti anomalies in these profiles points to the absence of residual amphibole in the mantle source. Interestingly, dry- or anhydrous conditions of boninite-source melting have been predicted by phase diagram relationships for high-Ca boninites (Crawford et al. 1989) and confirmed by experimental studies (Fallon and Danyushevsky 2000). Kanayama et al. (2013) have noted that dry, water-undersaturated conditions of fusion pertain to low-Si boninites $\left(\mathrm{SiO}_{2}<54 \mathrm{wt} \%\right)$, to which the Nové Město and Zábřeh boninites seemingly belong $\left(\mathrm{SiO}_{2}=47.4-52.1 \mathrm{wt} \%\right)$. 

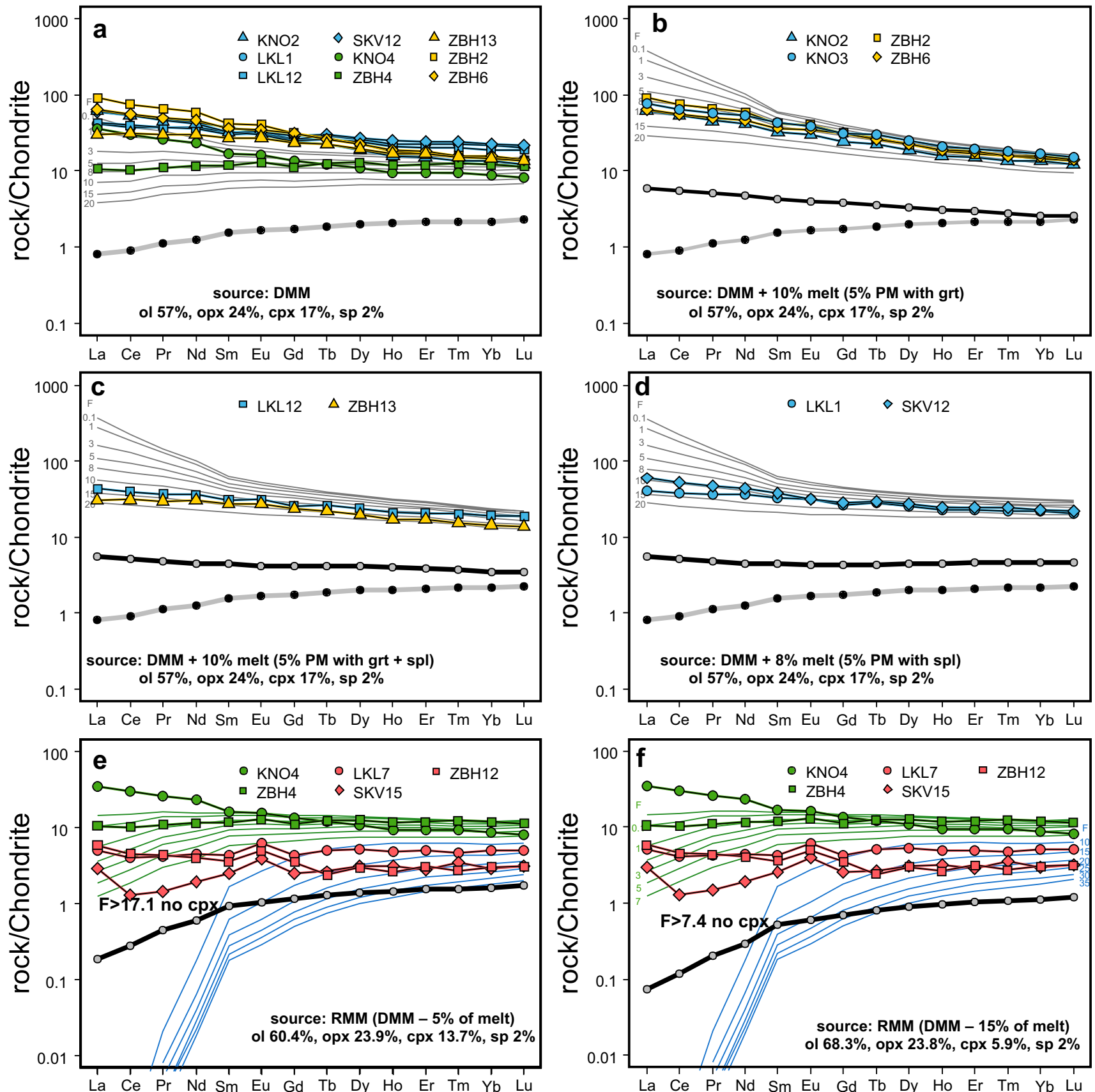

Fig. 8 REE diagrams with model curves of non-modal aggregated fractional melting in the spinel stability field (Woodhead et al. 1993) and mildly alkaline metabasites (KNO2, ZBH2, ZBH6), least fractionated, variously enriched meta-tholeiites (LKL1, LKL12, SKV12, ZBH13), low-Ti meta-tholeiites (KNO4, ZBH4) and meta-boninites (LKL7, SKV15, ZBH12). Model sources: a depleted mantle source (DMM), b metasomatized mantle (DMM mixed with $10 \%$ of OIBlike melt derived from $5 \%$ melting of primitive mantle with residual garnet), $\mathbf{c}$ metasomatized mantle (DMM mixed with $10 \%$ of OIB-like melt obtained from 5\% melting of primitive mantle, PM, with residual garnet and spinel), d metasomatized mantle (DMM mixed with $8 \%$ of OIB-like melt obtained from $5 \%$ melting of PM with residual spinel), e residual mantle (depleted DMM after 5\% non-modal batch

melting in spinel stability field), f residual mantle (depleted DMM after $15 \%$ non-modal batch melting in spinel stability field). Modal composition and melt mode: for DMM and metasomatized sources modified from Woodhead et al. (1993), for PM from Abdel-Rahman and Kumarapeli (1999), Aldanmaz et al. (2006) and Krienitz et al. (2006), for residual source modified from Woodhead et al. (1993) and Pagé et al. (2009). Mineral/melt partition coefficients for DMM and metasomatized source melting from Pagé et al. (2009) and Halliday et al. (1995); for PM melts from McKenzie and O'Nions (1991). Numbers in italics indicate the degree of partial melting (F). Composition DMM from Workman and Hart (2005) and PM from Sun and McDonough (1989). See text for discussion 
The prevailing view is that the petrogenesis of boninites is associated with refractory harzburgitic- or clinopyroxenepoor lherzolitic mantle extremely depleted in incompatible elements (Bédard 1999). Though boninite melts are estimated to form at shallow depths, within the spinel stability field ( 30-50 km), considerable heat input is required (e.g., Hickey and Frey 1982; Crawford et al. 1989; Bédard 1999; Fallon and Danyushevski 2000; Ishizuka et al. 2006; Pearce and Robinson 2010). Given the potential ambient mantle temperature $\left(1350 \pm 50{ }^{\circ} \mathrm{C}\right.$; Herzberg et al. 2010), a significant temperature increase is necessary to trigger melting (e.g., Falloon and Danyushevsky 2000). The thermal effect may be associated with lithospheric extension and asthenosphere upwelling in the form of OIB- or DMM-like diapirs within the mantle wedge (e.g., Jenner 1981; Hickey and Frey 1982; Crawford et al. 1989; Bedard 1999). It has also been postulated that substantial inflow of subducted slab-derived melts and fluid into the mantle wedge re-fertilizes it, considerably lowering its solidus temperature (e.g., Pearce and Parkinson 1993; Hawkesworth et al. 1993; Bédard 1999; Dilek and Thy 2009; König et al. 2010).

Estimations of P-T conditions for the generation of the Nové Město- and Zábřeh boninitic magmas give temperatures between 1400 and $1420{ }^{\circ} \mathrm{C}$ and pressures of 1.2-2.0 GPa (Fig. S5; LKL7 and SKV15) using the geothermobarometer of Lee et al. (2009). Values of mantle potential temperature $T_{\mathrm{p}}$ of boninitic-magma segregation obtained using the PRIMELTS3 software (Herzberg and Asimov 2015) yield temperatures of $1370-1500{ }^{\circ} \mathrm{C}$ that are close to the range of $1380-1460{ }^{\circ} \mathrm{C}$ for high-Ca boninites, compositionally similar to the Nové Město and Zábřeh metaboninites, that occur in North Tonga, Troodos in Cyprus

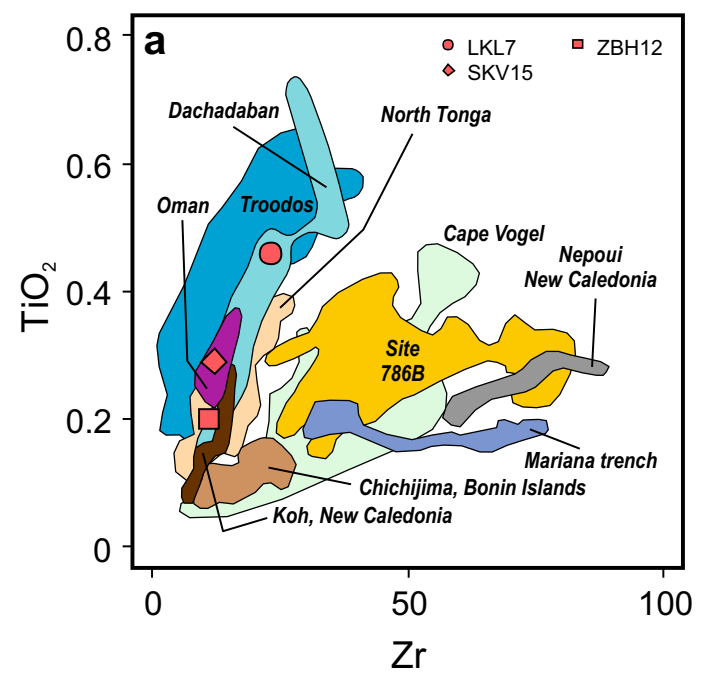

Fig. $9 \mathrm{TiO}_{2}$ vs $\mathrm{Zr}$ and $\mathrm{Ti} / \mathrm{Zr}$ vs $\mathrm{Zr} / \mathrm{Sm}$ diagram for the meta-boninites compared to high-Ca boninites (Troodos, North Tonga, Dachadaban, Oman and Koh) and low-Ca boninites (Cape Vogel, Nepoui, Mariana and Dachadaban in China (Sobolev and Danyushevski 1994; Xia et al. 2012; Figs. 9 and S7). In the case of the Nové Město and Zábřeh, a substantial thermal input is indicated as meta-boninites LKL7 and SKV15 formed at higher temperatures than the meta-tholeiites (Fig. S5) and higher than the average equilibration temperatures of $\sim 1300{ }^{\circ} \mathrm{C}$ for primitive arc lavas from intra-oceanic subduction zones (Perrin et al. 2016). The calculated $T_{p}$ for LKL7 and SKV15 also exceeds estimated values for the mantle wedge beneath backarc basins, e.g., $\sim 1350{ }^{\circ} \mathrm{C}$ for the Mariana trough and East Scotia ridge (Wiens et al. 2006). However, calculated $T_{\mathrm{p}}$ for meta-boninitic sample ZBH12 suggests much cooler conditions $\left(T_{\mathrm{p}} \sim 1300{ }^{\circ} \mathrm{C}\right.$; Fig. S5) and shallow levels $(\sim 40 \mathrm{~km})$ for melt formation. Its depleted composition (HREE abundances at $\sim 0.17 \times \mathrm{N}-\mathrm{MORB}$ ) indicates a very refractory mantle source likely to provide melt only at much higher temperatures. The difference seems to indicate boninite genesis associated with melts or fluids released into the mantle wedge. When compared (Figs. 3, S4), the subduction impact on sample SKV15 was relatively weak (substantial addition of La only, $\varepsilon \mathrm{Nd}$ of +6.7), moderate for LKL7 (elevated abundances of LREE and Th, $\varepsilon \mathrm{Nd}$ of +2.9) but strong for $\mathrm{ZBH} 12$ (high $[\mathrm{La} / \mathrm{Sm}]_{\mathrm{CN}}$ of $1.67, \varepsilon \mathrm{Nd}$ of -2.9 ). Moreover, the nearly horizontal baseline (Fig. S4) for ZBH12 suggests that not only LREE-MREE, but also some of $\mathrm{Nb}$ may have come from the subducted slab to the source. This would explain the marked contrast between the positive $\Delta \mathrm{Nd}$ $(+0.01)$ of ZBH12 and the negative $\Delta \mathrm{Nd}(-0.64)$ of LKL7 (Fig. 5b). This underscores the crucial role of subduction input in the origin of the meta-boninites and shows that only HREE may be confidently deemed conservative with respect to mantle-wedge composition.

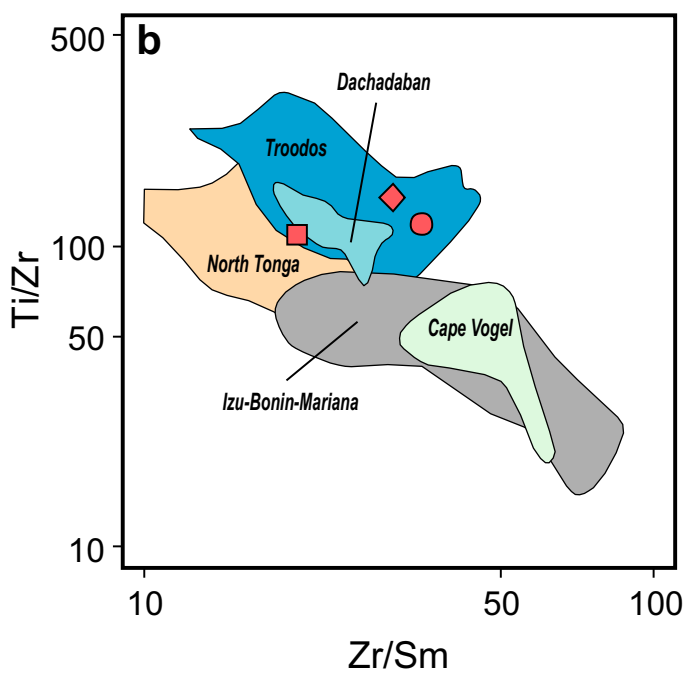

trench, Izu-Bonin-Marian, Chichijima, Site 786B). Compilation from Xia et al. (2012). See text for discussion 
The high temperatures $\left(1450-1500{ }^{\circ} \mathrm{C}\right)$ and enrichment of the mantle source of high-Ca boninites in North Tonga have led to some postulates involving an OIB-like mantle plume in their genesis (Samoa plume in the Lau basin; Sobolev and Danyushevsky 1994; Falloon et al. 2008; see also Hickey and Frey 1982). Such a prominent mantle-wedge component (as EM1, EM2 or HIMU) with its abundance of strongly incompatible trace elements (LREE-MREE, HFSE) and distinctive isotopic composition (e.g., Hofmann 2014; Willbold and Stracke 2010) would affect the composition of arc magmas produced. Some features of the metaboninites, e.g., their moderate-radiogenic to non-radiogenic $\mathrm{Nd}$ isotope compositions coupled with their enrichment in LREE-MREE and their slightly elevated $\mathrm{Zr}$, Hf and Ti abundances relative to $\mathrm{Sm}$ (Fig. 3), might be similarly interpreted. As discussed above, enriched, mildly alkaline metabasites also implicate input of EM1-EM2-like melts into the mantle wedge (Fig. 8b-d). However, any addition of OIB-like melt into strongly depleted residual-mantle regions would readily result in selective enrichment in HFSE, particularly $\mathrm{Nb}$ and Ta. Recently, Golowin et al. (2017) have shown that an addition as small as $\sim 0.06-1.0 \%$ of OIB-like (HIMU) melt into a residual mantle source suffices to produce positive $\mathrm{Nb}-\mathrm{Ta}$ anomalies and distinctly lower $\varepsilon \mathrm{Nd}$ values in boninite-like, low-Ti rocks from the Manihiki Plateau. Given that the meta-boninites have very low $\mathrm{Nb}$ concentrations $(\leq 0.5 \mathrm{ppm})$ and high $\mathrm{Th} / \mathrm{Nb}(0.30-0.77)$ relative to average OIB $(\mathrm{Nb}=48 \mathrm{ppm}, \mathrm{Th} / \mathrm{Nb}=0.08$; Sun and McDonough 1989), the influence of such melts in their origin seems unlikely in the light of the available data. Any substantial addition of such a component would also result in distinctly negative baseline slopes as seen for mildly alkaline samples, but not for meta-boninite samples (Fig. S4). Thus, the negative $\varepsilon \mathrm{Nd}$ values of the meta-boninite samples, as discussed in 5.2.2, are interpreted to fingerprint input from sedimentderived melts (LKL7 and ZBH12) or slab fluids (SKV15) into a region of residual mantle.

To reconstruct the mantle wedge source for the metaboninites protoliths (prior to subduction-related modification) and estimate the degree of its melting, geochemical modeling was undertaken. The modeling relies on HREE due to their low contents in subduction-derived components and moderate incompatibility (König et al. 2010). The model considers the refractory (residual) nature of the source and any depletion due to previous magmatic events. The petrogenesis of boninites is commonly associated with two-stage melting where less fertile clinopyroxene-poor or harzburgitic residue reflecting earlier extraction of tholeiitic magmas re-melts to provide liquids much depleted with regard to N-MORB in incompatible elements (e.g., Hickey and Frey 1982; Crawford et al. 1989; Bédard 1999; Falloon and Danyushevsky 2000; Pagé et al. 2009). The occurrence of the boninites together with tholeiites suggests that the boninitic source could have been a residue after $10-15 \%$ melting of DMM producing the tholeiitic precursor (Fig. 8b-d). Thus, a residual source after $15 \%$ of batch melting (RMM-15, approximation of maximum depletion in the mantle wedge) was calculated with appropriate adjustments of source mineral compositions (Fig. 8f). The FMMnormalized diagrams for the meta-boninites (Fig. 7) suggest that their source could have been less depleted, i.e., residual after $\sim 5 \%$ of DMM melting. Accordingly, an appropriate model source (RMM-5) was also calculated (Fig. 8e), providing a lower limit of mantle depletion. The DMM modal composition (modified from Woodhead et al. 1993) applied in the modeling and the mineral melt mode (Pagé et al. 2009) assume the disappearance of clinopyroxene at $21 \%$ melting and, hence, both RMM-5 and RMM-15 remained lherzolitic with lowered contents of the mineral. In the second stage modeling, aggregated non-modal fractional melting was applied. Clinopyroxene exhaustion at $17.1 \%$ and $7.4 \%$ melting of RMM-5 and RMM-15, respectively, turned the source into a spinel-harzburgite residue which was to be the object of further melting. The calculations assumed dry conditions of melting as there is no indication of amphibole in the source (discussed above in this section). The model melts obtained were then compared with three meta-boninite profiles (Fig. 8e, f). The plots contrast sharply for the LREE and MREE section, which stems from subduction-derived input and depicts the extent of that addition. In contrast, the lines coincide for HREE indicating 15-25\% melting of RMM-15 and 25-35\% melting of RMM-5. Both models demonstrate that harzburgitic mantle is required to account for the origin of the boninites. Both show consistently that samples SKV15, ZBH12 could have resulted from an almost uniform but greater extent of melting than sample LKL7. However, the maximum degree of fusion $(\sim 35 \%)$ predicted by melting of RMM-5 is very high compared to that most often postulated, i.e., 10-25\% (e.g., Bédard 1999; Pagé et al. 2009; König et al. 2010; Escuder-Viruete et al. 2011; Golowin et al. 2017). Even though higher degrees have been reported (<ca. 38\%; Escrig et al. 2012), the lower degree of melting seems more plausible and, thus, the model involving the RMM-15 source is preferred here.

The increase in degree of melting suggested by the calculations roughly mirrors the decrease of $\mathrm{CaO} / \mathrm{Al}_{2} \mathrm{O}_{3}$ from 1.14 for LKL7, to 0.81 for SKV15, to 0.64 for ZBH12 and accords with the opinion of Crawford et al. (1989) that a more refractory source or a higher-degree partial melting is characteristic for low- $\mathrm{Ca}\left(\mathrm{CaO} / \mathrm{Al}_{2} \mathrm{O}_{3}<0.75\right)$ types of boninite. Nevertheless, when compared to other boninitic rocks of established chemical affinity, e.g., high-Ca boninites from Troodos and North Tonga (König et al. 2008; Falloon et al. 2008) and low-Ca boninites from Cape Vogel in Papua New Guinea (König et al. 2010), the meta-boninites rather follow the high-Ca boninite 
trend and have similar Ti/Zr (Figs. 9 and S7). The high $\mathrm{Ti} / \mathrm{Zr}$ of the meta-boninites (109-145), close to the values for DMM (141) or primitive mantle (116), implies a lack of metasomatic $\mathrm{Ti}$ and $\mathrm{Zr}$ enrichment in the mantle region (Xia et al. 2012). A marked difference from other high-Ca boninites is evident only for LREE-MREE, a feature that probably reflects compositional variation in the slab-derived enrichments of their respective sources. In contrast to high-Ca boninites, low-Ca boninites have higher $\mathrm{Zr} / \mathrm{Sm}(>40)$ and $\mathrm{Zr} / \mathrm{Hf}(>30)$, and a show a distinct $\mathrm{Zr}$-Hf positive anomaly on N-MORB-normalized plots (Fig. S7). The elevated $\mathrm{Zr} / \mathrm{Sm}, \mathrm{Zr} / \mathrm{Hf}$ (and positive $\mathrm{Zr}-\mathrm{Hf}$ anomaly relative to $\mathrm{Sm}$ ) have been ascribed to modification of the boninitic source by melts released from slab with amphibolite- or eclogite residues (e.g., Pearce et al. 1992; König et al. 2010; Li et al. 2013). The meta-boninites have low values of $\mathrm{Zr} / \mathrm{Sm}$ (20.0-34.9) and $\mathrm{Zr} / \mathrm{Hf}(27.5-30.0)$ similar to other high-Ca boninites, e.g., Troodos $(\mathrm{Zr} / \mathrm{Sm} \mathrm{16}-32$, Zr/Hf 22-32; König et al. 2008) and Dachadaban, North Quilian (Zr/Sm 19-31, $\mathrm{Zr} / \mathrm{Hf}$ 28-38; Xia et al. 2012) that convincingly argue against residual amphibole in melting slab. The lack of a pronounced $\mathrm{Zr}-\mathrm{Hf}$ anomaly (either positive or negative) in the meta-boninites supposedly excludes the presence of residual rutile in the subducted slab (e.g., König et al. 2010; Li et al. 2013). These features argue against substantial addition of slab melts and strongly support a dominant role for melts or fluids derived from subducted sediment metasomatizing the source of the meta-boninites (see 5.2.2). More importantly, however, they show that $\mathrm{Zr}$, Hf and Ti remained conservative in the meta-boninite source and essentially reflect the pristine composition of residual mantle not disturbed by slab-derived additions.

The modeling further allows for some petrogenetic assessment of the low-Ti meta-tholeiites (samples KNO4 and ZBH4) which occur sporadically with the main groups of metabasites. Their FMM-normalized patterns $\mathrm{VHI} \geq \mathrm{HI} \approx \mathrm{MI}$ (Fig. 7) point to a high degree of partial melting of fertile, un-enriched mantle. However, the models suggest that their HREE abundances are satisfactorily reproduced by melting of lherzolite mantle, either unenriched (i.e., DMM-type) or residual (depleted by an earlier melt extraction, RMM-5 and RMM-15). With a DMM-type source, the degree of melting could have been moderate and range from $\sim 5$ to $10 \%$ (Fig. 8a), though re-melting of residual sources also seems viable for both samples. For KNO4, 7-10\% fusion yields magmas of similar composition and the results do not depend significantly on the degree of any earlier melting (Fig. 8e, f). ZBH4 has concentrations of HREE reflecting very low $(<3 \%)$ degrees of melting of residual mantle.

\section{Tectonic and regional implications}

Pervasive Variscan deformation and metamorphism effectively obliterated the original distribution of the different types of metabasite and the spatial relations between them and their surroundings. Because the age of the metabasite protoliths remains unknown, tectonic reconstructions and regional correlations must rely on geochemical features and general petrogenetic analogies.

The metabasites from the Nové Město- and Zábřeh Units are dominated by meta-tholeiites accompanied by rare lowTi meta-tholeiites and high-Ca meta-boninites. They derive from sources ranging from residual and refractory, to typical depleted MORB mantle (DMM), to variously metasomatized DMM (alkaline melts) involving heterogeneous, randomly distributed input from subducted slab. Continuous trends on discrimination diagrams run from intra-oceanictowards within-plate fields (Figs. 2b, 4a-c, h) or towards intra-oceanic- and island-arc fields (Fig. 4f, g) accord with the extensional supra-subduction regime of back-arc basins (BAB; e.g., Gribble et al. 1996; Pearce et al. 1995). A recent report on the coexisting Nové Město phyllites and mica schists also points to continental island-arc deposition of their protoliths in a BAB environment (Maliszewski and Ilnicki 2019). It is worth emphasizing that both the Nové Město Unit and the Zábřeh Unit coherently point to the same paleotectonic environment based on the data presented here. The most conspicuous difference concerns the degree of supra-subduction zone input, which should be no surprise given the complex structure of the BAB zone (Pearce and Stern 2006). Otherwise, the nature of the subduction component and OIB-like enrichment are similar, corroborating the genetic connection between the units.

The highly variable magnitude, or even absence, of the subduction signal observed in the metabasites (Fig. S4) is not atypical of the BAB tectonic environment. The distribution of subduction components within the mantle wedge may reflect proximity of the trench, distance to the descending slab (slab depth) and/or circulation and directions of flow to the supra-subduction zone (Pearce et al. 1995; Pearce and Peate 1995; Pearce and Stern 2006; Escrig et al. 2012; Zamboni et al. 2016). Increasing mantle-wedge depletion may also correlate with proximity to the arc front (e.g., Pearce and Stern 2006; Escrig et al. 2012). Due to the prevailing non-residual nature of the meta-tholeiite protolith magma source and variation in the subduction contribution, some distance to the trench (or subducted slab) is postulated. The same appears valid for the high-Ca meta-boninites as boninites emplaced closer to the fore-arc are of low-Ca type and frequently associated with BADR (basalt-andesite-dacite-rhyolite); whereas, those in the back-arc basin farther from the trench are of high-Ca type and occur with abundant mafic volcanics transitional from $\mathrm{N}$ - or E-MORB to 
island-arc tholeiites. These volcanics are characterized by erratic subduction zone input (Xia et al. 2012).

The within-plate style of enrichment of some meta-tholeiites, though mostly associated with basalts from oceanic islands, seamounts and continental rifts (e.g., McKenzie and O’Nions 1995; Fitton 2007), does not exclude the BAB environment. OIB-like and E-MORB melts, and $\mathrm{BAB}$, have been reported from both modern- and ancient supra-subduction zones (e.g., Pin and Waldhausrova 2007; Ilnicki et al. 2013; Zamboni et al. 2016; Windley and Xiao 2018). Although the origin of OIB-type magmas is commonly attributed to deep mantle-plume activity, may also appear in response to passive upwelling of asthenosphere and decompression melting of dispersed blobs of recycled crustal components (e.g., EM-1 and EM-2 types) carried by the upflow (e.g., Courtillot et al. 2003; Willbold and Stracke 2010; Hofmann 2014). Slab retreat and roll-back may induce a multi-directional flow of such asthenosphere around edges of subducted slab towards $\mathrm{BAB}$ or, in extensional regimes, upward diapiric migration (e.g., Pearce and Stern 2006; Pin and Waldhausrova 2007; Zamboni et al. 2016). Hot, sub-slab asthenosphere may also rise into the mantle wedge through slab windows and gaps due to slab detachment or ridge-trench collision; in this way, both heat and embedded components are introduced into the mantle wedge (e.g., Thorkelson 1996; Pin and Waldhausrova 2007; Scalabrino et al. 2009; Windley and Xiao 2018). Our geochemical modeling suggests that the OIB-like melts could have originated due to polybaric decompression melting triggered, most probably, by asthenospheric upwellings. In this way, both the injections of melts metasomatizing the mantle wedge and the heat required for boninite magma generation would be supplied (e.g., Hickey and Frey 1982; Crawford et al. 1989; Falloon and Danyushevsky 2000).

Furthermore, the appearance of boninite-type rocks in the metabasitic suites of the Nové Město- and Zábřeh Units provides crucial regional constraints for our palaeotectonic model. Boninites are exceptionally rare in the Bohemian Massif and, excepting the Central Sudetic ophiolite (Dubińska 1997), have been found only in the Teplá-Barrandian Unit (Vitková and Kachlík 2001; Kachlík et al. 2001; Sláma et al. 2008). These rocks occur as rare dykes and sills together with low-Ti tholeiites, andesites, dacites and rhyolite in the volcano-sedimentary succession of the Davle volcanic arc (ca. 608-563 Ma) and in the overlying Svrchnice Formation (ca. 560-520 Ma) comprising siliciclastic metasediments and bimodal volcanics of a relic back-arc basin (e.g., Kachlík et al. 2001; Hajná et al. 2018). Boninites represent a high-Ca type, strikingly similar to the meta-tholeiites (Fig. S7), that originates from variably metasomatized depleted mantle $\left(\varepsilon \mathrm{Nd}_{650}=+2.5\right.$ to +6 ; Kachlík et al. 2001; Vitková and Kachlík 2001). The origin of the Teplá-Barrandian boninites is correlated with the final stages of oblique, Pacific-type subduction of the Cadomian arc and accretion along the northwestern margin of Gondwana (e.g., Hajná et al. 2018). Intense arc activity in the Davle complex ceased at ca. $563 \mathrm{Ma}$ in response to either a change in plate convergence from frontal to more oblique (Hajná et al. 2017) or a switch to flat-slab subduction (Hajná et al. 2018). However, subduction continued until a period of sediment accretion at ca. $527 \mathrm{Ma}$ was immediately followed by emplacement of boninite dykes triggered by hot-ridge subduction at ca. 524-520 Ma and slab break-off. However, the age of these boninites is unknown but is constrained to ca. 544-524 Ma by the maximum ages of the host metasediments and of the meta-rhyolites of the overlying succession (Hajná et al. 2013).

In our opinion, a two-stage tectonic model which reconciles the $\mathrm{BAB}$ environment, the observed magma spectrum, the available regional inferences and a pivotal role for the boninites can explain the origin of the Nové Městoand Zábřeh metabasites (Fig. 10). During the first stage, tholeiitic magmas originated from a fertile, spinel-bearing DMM-type source at various depths (Fig. S5) due to upward migration of depleted mantle-wedge asthenosphere in a $\mathrm{BAB}$ extensional regime (Fig. 10a). The source was affected by metasomatism due to, firstly, subduction zone-related melts or fluids from subducted sediments associated with minor fluids from subducted juvenile crust and, secondly, OIB-like components from low-degree decompression melts derived from EM1-EM2 entities dispersed in the asthenosphere. The latter required asthenospheric upwelling and polybaric melting achievable by slab retreat and, ultimately, slab detachment. However, an alternative explanation based on tectonic reconstruction for the Teplá-Barrandian which assumes opening of the slab window due to oblique ridge-trench collision and marked by boninitic intrusions (Hajná et al. 2018) is favored here. Consequently, the second stage of our model begins with the upward flow of sub-slab asthenosphere through a slab window into the BAB zone (Fig. 10b). This would supply both OIB-type melts to modify the mantle wedge source and increased heat flow to trigger shallow melting of refractory regions. Eventually, this strongly heterogeneous reservoir would produce, respectively, enriched mildly alkaline- and boninite magmas. Emplacement of the latter, as in the Teplá-Barrandian, would define the final stages of $\mathrm{BAB}$ development as ridge-trench collision led to cessation of subduction zone activity.

Consequently, we argue that the unique presence of metaboninites in the Nové Město- and Zábřeh Units unequivocally identifies them as part of the Teplá-Barrandian Unit, a relationship hitherto postulated only on lithological grounds (e.g., Cháb et al. 1995). Presumably, together they constituted a portion of the Cadomian active margin where Iapetus slab subducted below the Gondwana upper plate, with the Nové Město- and Zábřeh Units in more distant (relative 
Fig. 10 Tectonic model for the Nové Město- and Zábřeh metabasites. Further explanation in text

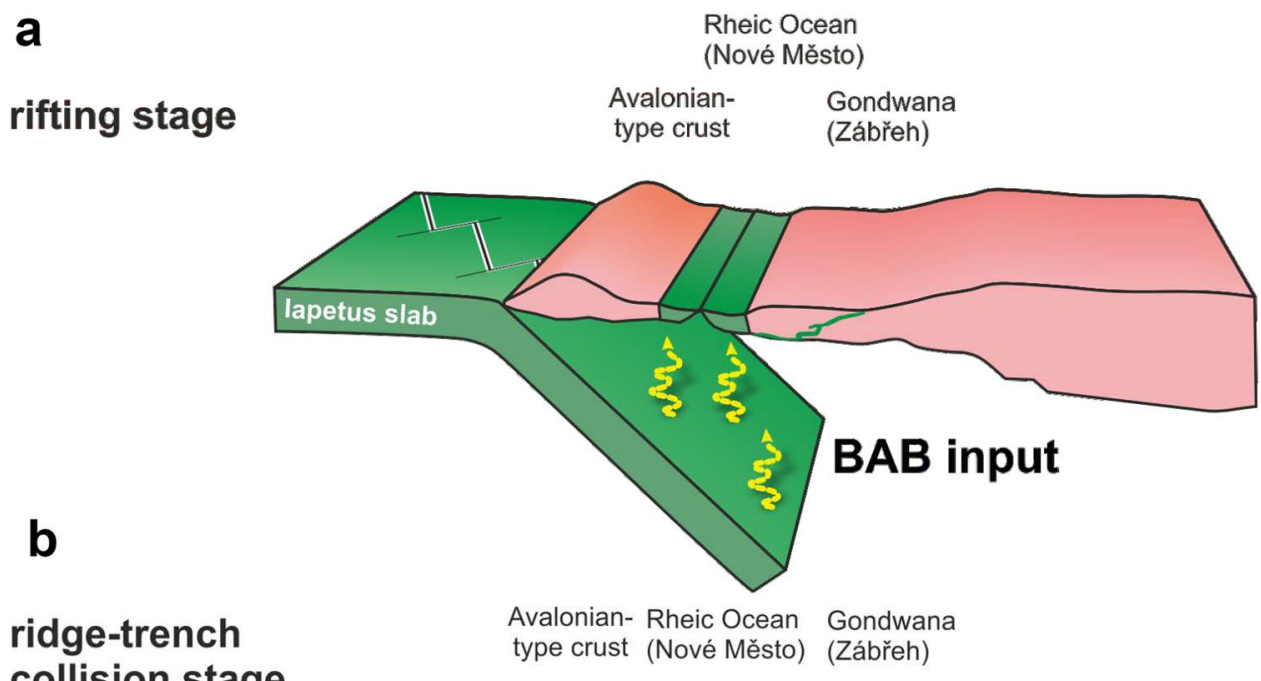

collision stage type crust (Nové Město) (Zábřeh)

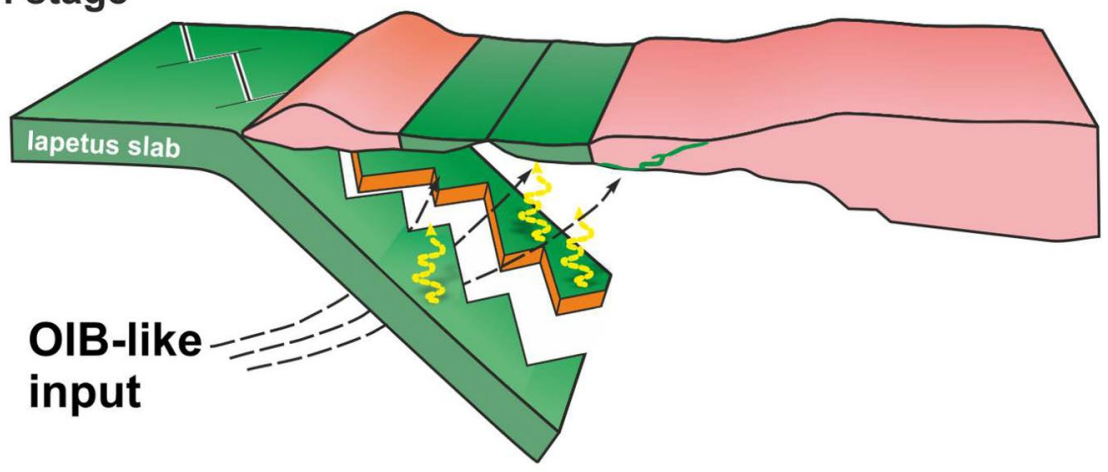

oceanic crust

Peri-Gondwanan continental crust

basic volcanics

to the trench) and mature parts of the BAB. Thus, in geodynamic models for the Teplá-Barrandian Unit, it would be a BAB domain located between the Davle arc complex and the Gondwana mainland (Fig. 13 in Hajná et al. 2017; 2018). It is now mostly truncated by the Central Bohemian pluton or buried below the Carboniferous sediments of the Intra-Sudetic Basin and Cretaceous sediments of the North Bohemian Basin. Though the distance of the two units to Gondwana is difficult to estimate, the proportions of supracrustal rocks and metabasites may suggest that the Zábřeh unit lay closest to the continent (Figs. 1 and 10b).

In summary, the structure of the Orlica-Śnieżnik Dome comprising units of Teplá-Barrandian affinity amalgamated during Variscan times with the Saxothuringian core (Chopin et al. 2012; Szczepański and Ilnicki 2014) records the diachronic cessation subduction zone activity preceded by $\mathrm{BAB}$ magmatism, and ridge-trench collision in once separated domains of the Avalonian-Cadomian belt (Hajna et al. 2018). Evidence of these events provided by the the Orlica-Śnieżnik Dome core metabasites (Ilnicki et al. 2013) reveals a history analogous to that presented here. However, the fact that the core of the Orlica-Śnieżnik Dome lacks boninites points to variations in temperature conditions and differing magnitudes of subduction input and offers, perhaps, an insight into the contrasting geometry and subduction style of the Teplá-Barrandian and Saxothuringian domains.

\section{Conclusions}

1. Metabasites from the Nové Město- and Zábřeh Units (west and south, respectively, envelope of the OrlicaŚnieżnik Dome, Central Sudetes) have nearly identical geochemical characteristics corresponding to variously enriched tholeiites and high-Ca, low-silica boninites and subordinate low-Ti tholeiites. Their genesis is related to a mature extensional back-arc basin located at some distance from the trench.

2. Fertile, albeit depleted, MORB mantle (DMM) was most probably the source of the tholeiitic melts. Geochemical modeling suggests that these parental magmas could have formed due to $10-15 \%$ shallow melting of the source region $\left(1380-1230{ }^{\circ} \mathrm{C}\right.$ at $\left.1.8-0.7 \mathrm{GPa}\right)$. Shortly before fusion, the source was heterogeneously metaso- 
matized by small amounts (8-10\%) of OIB-like melts extracted at various depths (garnet to spinel stability field) from enriched components (possibly EM1-EM2 type) in the mantle wedge.

3. High-Ca meta-boninites most probably reflect $15-25 \%$ re-melting of residual mantle, i.e., DMM after $\sim 15 \%$ extraction of tholeiitic melt at $1420-1400{ }^{\circ} \mathrm{C}$ to $1300{ }^{\circ} \mathrm{C}$ and pressures from 2.0 to $1.2 \mathrm{GPa}$. Geochemical models suggest that due to high degrees of melting the initial lherzolite source exhausted clinopyroxene and boninitic magma segregated from harzburgitic residue. The solidus of the refractory boninite source was likely lowered by subduction-related input.

4. The low-Ti meta-tholeiites may be attributed to $<10 \%$ melting of DMM-type source or to re-melting of residual mantle remaining after $<15 \%$ of former melting.

5. Tholeiitic- and boninitic magma sources were heterogeneously and randomly metasomatized in the main by melts and fluids released from subducted sediments into mantle wedge or from subducted juvenile crust. The inferred sediment composition, in terms of $\mathrm{Th} / \mathrm{La}$, compares to that of subducting sediments at trenches globally (GLOSS-II of Plank 2014).

6. The meta-tholeiites and meta-boninites of the Nové Město and Zábřeh Units point to strong genetic links between the envelope of the Orlica-Śnieżnik dome and the Teplá-Barrandian domain where volcanic arcs of the Cadomian subduction system are preserved. The inference is that both units are a vestigial, easterly prolongation of that system. The emplacement of high-Ca boninites and presumably polybaric OIB-like input into mantle beneath an extensional back-arc basin may mark the upflow of hot, sub-slab asthenosphere through a slab window opened in the course of ridge-trench collision, and subsequent cessation of subduction zone activity.

\footnotetext{
Acknowledgements The study was supported by Polish Ministry of Science and Higher Education Grant no. 2P04D2227. Grants from the Faculty of Geology, University of Warsaw (no. BSt-185704 and no. BSt-IGMiP-2007/1), and University of Wrocław (041/1017/18 zad. 3) are also gratefully acknowledged. C.P. is very grateful to J. Lancelot and P. Verdoux for generous access to the Triton mass spectrometer at the University of Nîmes. Reviews by Xiao Wenjiao and anonymous reviewer as well as editorial handling of the paper by Pavla Štípská and Wolf-Christian Dullo are highly appreciated. Oliwia Grafka is acknowledged for editorial help. The study benefited from the analytical facilities of the project RPO-WM 2007-2013 "Modernization and equipment supplement of laboratories at Faculty of Geology, University of Warsaw, for crucial environmental geo-engineering research and development of Mazovia: Stage 1". The authors are indebted to Padhraig Kennan (University College Dublin) for comments on the manuscript, and for language corrections.
}

Open Access This article is licensed under a Creative Commons Attribution 4.0 International License, which permits use, sharing, adaptation, distribution and reproduction in any medium or format, as long as you give appropriate credit to the original author(s) and the source, provide a link to the Creative Commons licence, and indicate if changes were made. The images or other third party material in this article are included in the article's Creative Commons licence, unless indicated otherwise in a credit line to the material. If material is not included in the article's Creative Commons licence and your intended use is not permitted by statutory regulation or exceeds the permitted use, you will need to obtain permission directly from the copyright holder. To view a copy of this licence, visit http://creativecommons .org/licenses/by/4.0/.

\section{References}

Abdel-Rahman AFM, Kumarapeli PS (1999) Geochemistry and petrogenesis of the Tibbit Hill metavolcanic suite of the Appalachian fold belt, Quebec-Vermont; a plume-related and fractionated. Am J Sci 299:210-237

Aldanmaz E, Köprübaşı N, Gürer ÖF, Kaymakçı N, Gourgaud A (2006) Geochemical constraints on the Cenozoic, OIB-type alkaline volcanic rocks of NW Turkey: Implications for mantle sources and melting processes. Lithos 86:50-76

Bachliński R, Hałas S (2002) K-Ar dating of biotite from the Kudowa Zdrój granitoids (Central Sudetes, SW Poland). Bull Pol Acad Sci Earth Sci 50:113-116

Bédard JH (1999) Petrogenesis of Boninites from the Betts Cove Ophiolite, Newfoundland, Canada: identification of subducted source components. J Petrol 40:1853-1889

Brennan JM, Shaw HF, Ryerson FJ, Phinney DL (1995) Mineral-aqueous fluid partitioning of trace elements at $900{ }^{\circ} \mathrm{C}$ and $2.0 \mathrm{GPa}$ : constraints on the trace element chemistry of mantle and deep crustal fluids. Geochim Cosmochim Acta 59:3331-3350

Buriánek D, Němečková M, Hanžl P (2003) Petrology and geochemistry of plutonic rocks from the Polička and Zábřeh crystalline units (NE Bohemian Massif). Bull Geosci Praha 78:9-22

Cabanis B, Lecolle M (1989) Le diagramme La/10-Y/15-Nb: un outil pour la discrimination des séries volcaniques et la mise en évidence des processus de mélange et/ou de contamination crustale. Comp Rend Acad Sci Ser II 309:2023-2029

Cháb J, Suchý V, Vejnar Z (1995) Metamorphic evolution. In: Dallmeyer RD, Franke W, Weber K (eds) Pre-Permian geology of Central and Eastern Europe. Springer, Berlin, pp 403-410

Chopin F, Schulmann K, Skrzypek E, Lehmann J, Dujardin JR et al (2012) Crustal influx, indentation, ductile thinning and gravity redistribution in a continental wedge: Building a Moldanubian mantled gneiss dome with underthrust Saxothuringian material (European Variscan belt). Tectonics. https://doi. org/10.1029/2011TC002951

Courtillot V, Davaille A, Besse J, Stock J (2003) Three distinct types of hotspots in the Earth's mantle. Earth Planet Sci Lett 205:295-308

Crawford AJ, Falloon TJ, Green DH (1989) Classification, petrogenesis and tectonic setting of boninites. In: Crawford AJ (ed) Boninites and related rocks. Unwin Hyman, London, pp 1-49

DePaolo DJ (1981) Trace element and isotopic effects of combined wallrock assimilation and fractional crystallization. Earth Planet Sci Lett 53:189-202

Dilek Y, Furnes H, Shallo M (2007) Suprasubduction zone ophiolite formation along the periphery of Mesozoic Gondwana. Gondwana Res 11:453-475

Dilek Y, Furnes H (2009) Structure and geochemistry of Tethyan ophiolites and their petrogenesis in subduction rollback systems. Lithos 113:1-20

Dilek Y, Thy P (2009) Island arc tholeiite to boninitic melt evolution of the Cretaceous Kizildag (Turkey) ophiolite: model for 
multi-stage early arc-forearc magmatism in Tethyan subduction factories. Lithos 113:68-87

Dilek Y, Furnes H (2014) Ophiolites and their origins. Elements 10:93-100

Dubińska E (1997) Rodingites and amphibolites from the serpentinites surrounding Sowie Góry Block (Lower Silesia, Poland): record of supra-subduction zone magmatism and serpentinisation. $\mathrm{N} \mathrm{Jb}$ Miner Abh 171:239-279

Elliott T (2003) Tracers of the slab. AGU Geophys Monogr 138:23-45

Ersoy Y, Helvac1 C (2010) FC-AFC-FCA and mixing modeler: a Microsoft ${ }^{\circledR}$ Excel $^{\circledR}$ spreadsheet program for modeling geochemical differentiation of magma by crystal fractionation, crustal assimilation and mixing. Comput Geosci 36:383-390

Escrig S, Bézos A, Langmuir CH, Michael PJ, Arculus R (2012) Characterizing the effect of mantle source, subduction input and melting in the Fonualei Spreading Center, Lau Basin: constraints on the origin of the boninitic signature of the back-arc lavas. Geochem Geophys Geosyst. https://doi.org/10.1029/2012GC004130

Escuder-Viruete J, Friedman R, Castillo-Carrión M, Jabites J, PérezEstaún A (2011) Origin and significance of the ophiolitic high-P mélanges in the northern Caribbean convergent margin: insights from the geochemistry and large-scale structure of the Río San Juan metamorphic complex. Lithos 127:483-504

Falloon TJ, Danyushevsky LV (2000) Melting of refractory mantle at 1.5, 2 and $2.5 \mathrm{GPa}$ under anhydrous and $\mathrm{H}_{2} \mathrm{O}$-undersaturated conditions: implications for the petrogenesis of high-Ca boninites and the influence of subduction components on mantle melting. J Petrol 41:257-283

Falloon TJ, Danyushevsky LV, Crawford TJ, Meffre S, Woodhead JD, Bloomer SH (2008) Boninites and Adakites from the Northern termination of the tonga trench: implications for adakite petrogenesis. J Petrol 49:697-715

Fitton JG (2007) The OIB paradox. In: Foulger GR, Jurdy DM (eds) Plates, plumes and planetary processes, vol 430. Geol Soc Amer Spec Pap, London, pp 387-412

Fitton JG, Saunders AD, Norry MJ et al (1997) Thermal and chemical structure of the Iceland plume. Earth Planet Sci Lett 153:197-208

Floyd PA, Winchester JA, Ciesielczuk J, Lewandowska A, Szczepański J, Turniak K (1996) Geochemistry of early Palaeozoic amphibolites from the Orlica-Śnieżnik Dome, Bohemian Massif; petrogenesis and palaeotectonic aspects. Geol Rundsch 85:225-238

Golowin R, Portnyagin M, Hoernle K et al (2017) Boninite-like intraplate magmas from Manihiki Plateau require ultra-depleted and enriched source components. Nat Commun 8:14322. https://doi. org/10.1038/ncomms 14322

Gribble RF, Stern RJ, Bloomer SH, Stuben D, O'Hearn T, Newman S (1996) MORB and subduction components interact to generate basalts in the southern Mariana Trough back-arc basin. Geochim Cosmochim Acta 60:2153-2166

Ghiorso MS, Gualda GAR (2015) $\mathrm{An} \mathrm{H}_{2} \mathrm{O}-\mathrm{CO}_{2}$ mixed fluid saturation model compatible with rhyolite-MELTS. Contrib Miner Petrol 169:53

Gualda GAR, Ghiorso MS, Lemons RV, Carley TL (2012) RhyoliteMELTS: a modified calibration of MELTS optimized for silicarich, fluid-bearing magmatic systems. J Petrol 53:875-890

Hajná J, Žák J, Dörr W (2017) Time scales and mechanisms of growth of active margins of Gondwana: a model based on detrital zircon ages from the Neoproterozoic to Cambrian Blovice accretionary complex, Bohemian Massif. Gondwana Res 42:63-83

Hajná J, Žák J, Dörr W, Kachlík V, Sláma J (2018) New constraints from detrital zircon ages on prolonged, multiphase transition from the Cadomian accretionary orogen to a passive margin of Gondwana. Precambrian Res 317:159-178

Hajná J, Žák J, Kachlík V, Dörr W, Gerdes A (2013) Neoproterozoic to Early Cambrian Franciscan-type melanges in theTeplaBarrandian unit, Bohemian Massif: evidence of modern-style accretionary processes along the Cadomian active margin of Gondwana? Precambrian Res 224:653-670

Halliday AN, Lee D-C, Tommasini S et al (1995) Incompatible trace elements in OIB and MORB and source enrichment in the suboceanic mantle. Earth Planet Sci Lett 133:379-395

Hawkesworth CJ, Gallagher K, Hergt JM, McDermott F (1993) Mantle and slab contributions in ARC magmas. Annu Rev Earth Planet Sci 21:175-204

Hawkesworth CJ, Turner S, Peate D, McDermott F, van Calsteren P (1997) Elemental U and Th variations in island arc rocks: implications for U-series isotopes. Chem Geol 139:207-221

Herzberg C, Asimow PD (2015) PRIMELT3 MEGA.XLSM software for primary magma calculation: Peridotite primary magma $\mathrm{MgO}$ contents from the liquidus to the solidus. Geochem Geophys Geosys 16:563-578. https://doi.org/10.1002/2014GC005631

Herzberg C, Condie K, Korenaga J (2010) Thermal history of the Earth and its petrological expression. Earth Planet Sci Lett 292:79-88

Hickey RL, Frey FA (1982) Geochemical characteristics of boninite series volcanics: implications for their source. Geochim Cosmochim Acta 46:2099-2115

Hofmann AW (2014) Sampling mantle heterogeneity through oceanic basalts: isotopes and trace elements. Treatise Geochem. https:// doi.org/10.1016/B978-0-08-095975-7.00203-5

Ilnicki S (2013) Metabazyty pasma Nového Města. Arch Mineral Monogr 5:1-204

Ilnicki S, Szczepański J, Pin C (2013) From back-arc to rifted margin: geochemical and $\mathrm{Nd}$ isotopic records in Neoproterozoic?Cambrian metabasites of the Bystrzyckie and Orlickie Mountains (Sudetes, SW Poland). Gondwana Res 23:1104-1121

Ishizuka O, Kimura J-I, Li YB, Stern RJ, Reagan MK, Taylor RN, Ohara Y, Bloomer SH, Ishii T, Hargrove US, Haraguchi S (2006) Early stages in the evolution of Izu-Bonin arc volcanism: new age, chemical, and isotopic constraints. Earth Planet Sci Lett 250:385-401

Jenner GA (1981) Geochemistry of high-Mg andesites from Cape Vogel, Papua New Guinea. Chem Geol 33:307-332

Johnson MC, Plank T (2000) Dehydration and melting experiments constrain the fate of subducted sediments. Geochem Geophys Geosyst 1:1007. https://doi.org/10.1029/1999GC000014

Kanayama K, Kitamura K, Umino S (2013) New geochemical classification of global boninites. IAVCEI Sci Assem 99:1

Kachlík V, Janoušek V, Heřmánek R, Vítková R (2001) Whole-rock geochemistry and nd isotopic composition of metavolcanics from the Netvořice-Neveklov and Sedlčany-Krásná Hora islets: their petrogenesis and implications for geodynamic processes at the Teplá-Barrandian-Moldanubian boundary. Geolines 13:72-73

König S, Münker C, Schuth S et al (2010) Boninites as windows into trace element mobility in subduction zones. Geochim Cosmochim Acta 74:684-704

König S, Münker C, Schuth S, Garbe-Schönberg D (2008) Mobility of tungsten in subduction zones. Earth Planet Sci Lett 274:82-92

Krienitz M-S, Haase KM, Mezger K et al (2006) Magma genesis and crustal contamination of continental intraplate lavas in northwestern Syria. Contrib Mineral Petrol 151:698-716

Lee C-TA, Luffi P, Plank T et al (2009) Constraints on the depths and temperatures of basaltic magma generation on Earth and other terrestrial planets using new thermobarometers for mafic magmas. Earth Planet Sci Lett 279:20-33

LeFèvre B, Pin C (2005) A straightforward separation scheme for concomitant $\mathrm{Lu}-\mathrm{Hf}$ and $\mathrm{Sm}-\mathrm{Nd}$ isotope ratio and isotope dilution analysis. Analyt Chim Acta 543:209-221

Li YB, Kimura JI, Machida S et al (2013) High-Mg adakite and low$\mathrm{Ca}$ boninite from a bonin fore-arc seamount: Implications for the reaction between slab melts and depleted mantle. J Petrol 54:1149-1175 
Maliszewski K, Ilnicki S (2019) Back-arc basin affinities of the Nové Město (Central Sudetes) metasediment protholiths: results of major and trace element provenance study. Geophys Res Abstr 21:2019-14769

Mazur S, Aleksandrowski P, Szczepański J (2005) The presumed Teplá-Barrandian/Moldanubian terrane boundary in the Orlica Mountains (Sudetes, Bohemian Massif): structural and petrological characteristics. Lithos 82:85-112

Mazur S, Kröner A, Szczepański J, Turniak K, Hanžl P, Melichar R, Rodionov NV, Paderin I, Sergeev SA (2010) Single zircon U/Pb ages and geochemistry of granitoid gneisses from SW Poland: evidence for an Avalonian affinity of the Brunian microcontinent. Geol Mag 147:508-526. https://doi.org/10.1017/S0016 $75680999080 X$

Mazur S, Szczepański J, Turniak K, McNaughton NJ (2012) Location of the Rheic suture in the eastern Bohemian Massif: evidence from detrital zircon data. Terra Nova 24:199-206

Mazur S, Turniak K, Szczepański J, McNaughton NJ (2015) Vestiges of Saxothuringian crust in the Central Sudetes, Bohemian Massif: Zircon evidence of a recycled subducted slab provenance. Gondwana Res 27:825-839

McKenzie D, O’Nions RK (1991) Partial melt distributions from inversion of rare earth element concentrations. J Petrol 32:1021-1091

McKenzie D, O'Nions RK (1995) The source regions of ocean island basalts. J Petrol 36:133-159

Melichar R, Hanžl P (1997) Lithotectonic correlation of the Polička and Zábřeh Crystalline units. J Czech Geol Soc 42:64

Meschede M (1986) A method of discriminating between different types of mid-ocean ridge basalts and continental tholeiites with the $\mathrm{Nb}-\mathrm{Zr}-\mathrm{Y}$ diagram. Chem Geol 56:207-218

Mísař Z, Dudek A (1993) Some critical events in the geological history of eastern margin of the Bohemian Massif. J Czech Geol Soc 38:9-20

Nance RD, Gutiérrez-Alonso G, Keppie JD, Linnemann U, Murphy JB, Quesada C, Strachan RA, Woodcock NH (2010) Evolution of the Rheic Ocean. Gondwana Res 17:194-222

Opletal M, Jelínek E, Pecina V, Pošmurný K, Poubová E (1990) Metavolcanites of the SE part of the Lugicum, their geochemistry and geotectonic interpretation. Sbor Gelog Věd 45:37-64

Pagé P, Bédard JH, Tremblay A (2009) Geochemical variations in a depleted fore-arc mantle: the Ordovician Thetford Mines Ophiolite. Lithos 113:21-47

Pearce JA (2008) Geochemical fingerprinting of oceanic basalts with applications to ophiolite classification and the search for Archean oceanic crust. Lithos 100:14-48

Pearce JA (2014) Immbolie element fingerprinting of ophiolites. Elements 10:101-108

Pearce JA, Ernewein M, Bloomer SH, Parson LM, Murton BJ, Johnson LE (1995) Geochemistry of Lau Basin volcanic rocks: Influence of ridge segmentation and arc proximity. In: Smellie JL (ed) Volcanism associated with extension at consuming plate margins, vol 81. Geol Soc London Spec Publ, London, pp 53-75

Pearce JA, Lann SR, Arculus RJ, Murton BJ, Ishii T, Peate DW, Parkinson IJ (1992) Boninite and harzburgite from Leg 125 (BoninMariana fore-arc): A case study of magma genesis during the initial stages of subduction. In: Fryer P, Peace JA, Stokking LB (eds) Proceedings of the OceanDrilling Program, Scientific Results, vol 125. Ocean Drilling Program Press, College Station, pp 623-659

Pearce JA, Norry MJ (1979) Petrogenetic implications of Ti, Zr, Y, and $\mathrm{Nb}$ variations in volcanic rocks. Contrib Mineral Petrol 69:33-47

Pearce JA, Parkinson IJ (1993) Trace element models for mantle melting: application to volcanic arc petrogenesis. Geol Soc Lond Spec Publ 76:373-403
Pearce JA, Peate DW (1995) Tectonic implications of the composition of volcanic arc magmas. Annu Rev Earth Planet Sci 23:251-285

Pearce JA, Robinson PT (2010) The Troodos ophiolitic complex probably formed in a subduction initiation, slab edge setting. Gondwana Res 18:60-81

Pearce JA, Stern RJ (2006) Origin of back-arc basin magmas: trace element and isotope perspectives. AGU Geophys Monogr Ser 166:63-86

Peate DW, Pearce JA, Hawkesworth CJ et al (1997) Geochemical variations in vanuatu arc lavas: the role of subducted material and a variable mantle wedge composition. J Petrol 38:1331-1358

Perrin A, Goes S, Prytulak J et al (2016) Reconciling mantle wedge thermal structure with arc lava thermobarometric determinations in oceanic subduction zones. Geochem Geophys Geosyst 17:4105-4127. https://doi.org/10.1002/2016GC006527

Pin C, Paquette JL (1997) A mantle-derived bimodal suite in the Hercynian Belt: Nd isotope and trace element evidence for a subduction-related rift origin of the Late Devonian Brê̂venne metavolcanics, Massif Central (France). Contrib Miner Petrol 129:222-238

Pin C, Santos Zalduegui JF (1997) Sequential separation of light rareearth elements, thorium and uranium by miniaturized extraction chromatography: application to isotopic analyses of silicate rocks. Analyt Chim Acta 339:79-89

Pin C, Telouk P, Imbert JL (1995) Direct determination of the samarium-neodymium ratio in geological materials by inductively coupled plasma quadrupole mass spectrometry with cryogenic desolvation. comparison with isotope dilution thermal ionization mass spectrometry. J Anal Atom Spectrom 10:93-98

Pin C, Waldhausrová J (2007) Sm-Nd isotope and trace element study of Late Proterozoic metabasalts ("spilites") from the Central Barrandian domain (Bohemian Massif, Czech Republic). In: Linnemann U, Nance RD, Kraft P, Zulauf G (eds) The evolution of the Rheic Ocean: From Avalonian-Cadomian active margin to Alleghenian-Variscan collision, vol 423. Geol Soc America Spec Paper, London, pp 231-247

Plank T (2014) The chemical composition of subducting sediments. Treatise Geochem. https://doi.org/10.1016/B978-0-08-09597 5-7.00319-3

Plank T (2005) Constraints from Thorium/Lanthanum on sediment recycling at subduction zones and the evolution of the continents. J Petrol 46:921-944

Reagan MK, Pearce JA, Petronotis K, Almeev RR, Avery AJ, Carvallo C, Chapman T, Christeson GL, Ferré EC, Godard M (2017) Subduction initiation and ophiolite crust: new insights from IODP drilling. Int Geol Rev 59:1439-1450

Saccani E (2015) A new method of discriminating different types of post-Archean ophiolitic basalts and their tectonic significance using $\mathrm{Th}-\mathrm{Nb}$ and $\mathrm{Ce}-\mathrm{Dy}-\mathrm{Yb}$ systematics. Geosci Front 6:481-501

Sánchez Lorda ME, García de Madinabeitia S, Pin C, Gil Ibarguchi JI (2012) Concomitant measurement of ${ }^{143} \mathrm{Nd} /{ }^{144} \mathrm{Nd}$ and ${ }^{147} \mathrm{Sm} /{ }^{144} \mathrm{Nd}$ ratios without isotope dilution in geological samples: an assessment of MC-ICP-MS capabilities. Int J Mass Spectrom 333:34-43

Scalabrino B, Lagabrielle Y, de la Rupelle A, Malavieille J, Polvé M, Espinoza F, Morata D, Suarez M (2009) Subduction of an active spreading ridge beneath Southern South America: a review of the cenozoic geological records from the Andean Foreland, Central Patagonia $\left(46-47^{\circ} \mathrm{S}\right)$. In: Lallemand S, Funiciello F (eds) Subduction zone geodynamics. Springer, Berlin, pp 227-246

Shervais JW (1982) Ti-V plots and the petrogenesis of modern and ophiolitic lavas. Earth Planet Sci Lett 59:101-118

Sláma J, Dunkley DJ, Kachlík V, Kusiak MA (2008) Transition from island-arc to passive setting on the continental margin of 
Gondwana: U-Pb zircon dating of Neoproterozoic metaconglomerates from the SE margin of the Teplá-Barrandian Unit, Bohemian Massif. Tectonophysics 461:44-59

Sobolev AV, Danyushevsky LV (1994) Petrology and geochemistry of boninites from the north termination of the Tonga trench: Constraints on the generation conditions of primary high-Ca boninite magmas. J Petrol 35:1183-1211

Stolz AJ, Jochum KP, Spettel B, Hofmann AW (1996) Fluid- and meltrelated enrichment in the subarc mantle: Evidence from $\mathrm{Nb} / \mathrm{Ta}$ variations in island-arc basalts. Geology 24:587-590

Sun SS, McDonough WF (1989) Chemical and isotopic systematics of oceanic basalts: implications for mantle composition and processes. Geol Soc Lond Spec Publ 42:313-345

Szczepański J, Ilnicki S (2014) From Cadomian arc to Ordovician passive margin: geochemical records preserved in metasedimentary successions of the Orlica-Śnieżnik Dome in SW Poland. Int J Earth Sci 103:627-647

Taylor SR, McLennan SM (1995) The geochemical evolution of the continental crust. Rev Geophys 33:241-265

Thorkelson DJ (1996) Subduction of diverging plates and the principles of slab window formation. Tectonophysics 255:47-63

Verner K, Buriánek D, Vrána S, Vondrovic L, Pertoldova J, Hanžl P, Nahodilová R (2009) Tectonometamorphic features of geological units along the northern periphery of the Moldanubian Zone. $\mathrm{J}$ Geosci 54:87-100

Vítková P, Kachlík V (2001) Petrology and geochemistry of high-Mg mafic metavolcanics sequence of the Sedlčany-Krásná Hory metamorphic "Islet", Central Bohemian Pluton, Czech Republic. Krystalinikum 27:7-25

Wiens DA, Kelley KA, Plank T (2006) Mantle temperature variations beneath back-arc spreading centers inferred from seismology, petrology, and bathymetry. Earth Planet Sci Lett 248:30-42

Willbold M, Stracke A (2010) Formation of enriched mantle components by recycling of upper and lower continental crust. Chem Geol 276:188-197
Wilson M (1993) Igneous petrogenesis: a global tectonic approach. Chapman and Hall, London, pp 1-466

Winchester JA, Floyd PA (1977) Geochemical discrimination of different magma series and their differentiation products using immobile elements. Chem Geol 20:325-343

Windley BF, Xiao W (2018) Ridge subduction and slab windows in the Central Asian Orogenic Belt: Tectonic implications for the evolution of an accretionary orogen. Gondwana Res 61:73-87

Woelkl D, Regelous M, Haase KM et al (2018) Petrogenesis of boninitic lavas from the Troodos Ophiolite, and comparison with Izu-Bonin-Mariana fore-arc crust. Earth Planet Sci Lett 498:203214. https://doi.org/10.1016/j.eps1.2018.06.041

Wood DA (1980) The application of a Th-Hf-Ta diagram to problems of tectonomagmatic classification and to establishing the nature of crustal contamination of basaltic lavas of the British Tertiary Volcanic Province. Earth Planet Sci Lett 50:11-30

Woodhead J, Eggins S, Gamble J (1993) High field strength and transition element systematics in island arc and back-arc basin basalts: evidence for multi-phase melt extraction and a depleted mantle wedge. Earth Planet Sci Lett 114:491-504

Workman RK, Hart SR (2005) Major and trace element composition of the depleted MORB mantle (DMM). Earth Planet Sci Lett 231:53-72

Xia X, Song S, Niu Y (2012) Tholeiite-boninite terrane in the North Qilian suture zone: implications for subduction initiation and back-arc basin development. Chem Geol 328:259-277

Zamboni D, Gazel E, Ryan JG et al (2016) Contrasting sediment melt and fluid signatures for magma components in the Aeolian Arc: implications for numerical modeling of subduction systems. Geochem Geophys Geosys 17:2034-2053. https://doi. org/10.1002/2016GC006301

Zindler A, Hart S (1986) Chemical geodynamics. Annu Rev Earth Planet Sci 14:493-571 